\title{
On Gentilidade as a Religious Offence: A Specificity of the Portuguese Inquisition in Asia?
}

\author{
Miguel Rodrigues Lourenço
}

The transfer of the Iberian Inquisitions to the overseas territories of Portugal and Spain in 156o and 1569-71 impacted the functioning of these tribunals in ways that were by no means superficial - to the extent that this institution was challenged by problems that it had not anticipated and for which it was only minimally prepared. Despite being an institution that was intended to be uniform in its organization and procedures, in African, American, and Asian contexts, the Inquisition was forced to adjust its models of surveillance as they were practiced in the Iberian Peninsula.

The territories where the Crown - and by extension, the Holy Officeclaimed jurisdiction encompassed large geographies that contrasted with the Iberian/European background that provided the social and religious matrix on which the jurisprudence practiced by the inquisitorial courts was based. Modern Inquisitions were heirs to a centuries-old process of adapting, employing, and defining the vocabulary relating to transgression and orthodoxy. Drawing from different social settings of Greek-Roman society, early Christian authors employed terms such as "sect", "heresy", or "superstition" to structure the basic discourse on faith and religion. ${ }^{1}$ The theological sophistication that ensued from the need to differentiate Christian orthodoxy from other groups claiming doctrinal authority also fostered a heresiological discourse that named, classified, and defined religious dissention to the point that it resulted in the production of handbooks on heresies, while Roman courts were making use of their own terminology to address charges of religious dissention. ${ }^{2}$ Thus, the

1 See Le Boulluec, La notion d'héresie; Sachot, "Religio/superstitio", 355-394; Boulhol, "Secta: de la ligne de conduite au groupe hétérodoxe", 5-33; Humfress, "Roman law, forensic argument and the formation of Christian Orthodoxy", 125-147.

2 McClure, "Handbooks against heresy in the West", 186-197; Humfress, "Roman law, forensic argument and the formation of Christian Orthodoxy", 131-142; Humfress, Orthodoxy and the Courts in Late Antiquity, esp. chapter 9, Heresy and the Courts, 243-268. 
Portuguese and Spanish Inquisitions inherited a theological and legal tradition that bequeathed to each of their individual courts not only an organized classification of the typologies of offences, but also paradigms of the specific behaviors or practices that indicated them. In these predetermined formats of delinquent behavior lay the conviction that the Holy Office could uniformly pass judgment on any offences to religion in any Christian (Catholic) society. In light of this, the non-European religious background with which the bishops (in the American domains of the Habsburgs) and inquisitors (of the Portuguese tribunals) were confronted was not a problem in itself. Every behavior with possible implications against the Catholic faith was liable to translation into available categories of offence, being framed and judged accordingly, regardless of the fact that attitudes perceived as religious could stem from long-standing local, non-European traditions. ${ }^{3}$

The debate on the miserable condition of the Indians and their rusticity and ignorance, which was the basis for King Philip II's decision to exclude them from inquisitorial jurisdiction, did not alter this fundamental assumption. ${ }^{4}$ The behaviors of the converted Indians-now under the jurisdiction of the Episcopal courts - continued to be framed in a grid of offences that classified them as "idolatry", "superstition", etc. ${ }^{5}$ In Portugal and its domains, despite the fact that there were no noticeable cases of capital punishment of neophytes, as occurred in New Spain, ${ }^{6}$ the debate on the nature of the Indians was still present in some institutional choices of the Crown. ${ }^{7}$ Nevertheless, Africans, Amerindians, and Asians remained under the jurisdiction of the Inquisition and the argument about the rusticity and ignorance of the Indians was applied

3 In her discussion of the formation of Christian orthodoxy, Humfress emphasized how Roman courts had pre-existing legal categories in order to lawfully create a jurisdictional space under which offences against orthodoxy could be judged. Humfress, "Roman law, forensic argument and the formation of Christian Orthodoxy", 131-142.

4 Castañeda Delgado, "La condición miserable del indio y sus privilegios", 245-335; Alberro, Inquisición y Sociedad en México, 21-22; Zaballa Beascoechea, "Del viejo al nuevo mundo", 28-34; Lara Cisneros, ¿Ignorancia invencible?, 67-91.

5 Zaballa Beascoechea, "Visitadores, extirpadores y "tratados de idolatrías", 258-280; Traslosheros, "Los indios, la Inquisición y los tribunales eclesiásticos en Nueva España", 47-74; Lara Cisneros, ¿Ignorancia invencible?, 91-117; Bernand and Gruzinski, De la idolatría, 129-171.

6 Bruno Feitler recently pointed out how little is known about the re-entry of apostates into the Catholic society in the Estado da Índia, beyond the fact that it involved a form of public penance. Feitler, "The Portuguese Inquisition and Colonial Expansion", 114; Mendonça, Conversions and Citizenry, 298.

7 Cardim, "Os povos indígenas e as instâncias de justiça na América portuguesa e espanhola", $33-38,44-45,5^{2-}-55$. 
to inquisitorial praxis, as recently demonstrated by Maria Leônia Chaves de Resende. ${ }^{8}$ Thus, in Portuguese courts that held jurisdiction over territories with a remarkable number — often the majority — of converted inhabitants, such as Lisbon and Goa, the same principle was applied, meaning that a transgressive behavior could be translated into a crime codified in law. However, in Goa, host to the only Portuguese court of the Holy Office ever to be established in a colonial territory — and with exclusively non-European territories under its jurisdiction - the inquisitors conducted trials for offences which they labeled gentilidade, of which a direct equivalent in Portuguese- or Spanish-American colonial territories is absent.

This chapter analyzes the emergence of gentilidade as a category of religious offence and discusses its uniqueness in the context of the Portuguese inquisitorial system. First, the discussion focuses on how this term, which was specifically used to signify the cultural-religious context of "Gentiles" (non-Christian, non-Jewish, and non-Muslim populations), came to be employed as a category of religious misconduct by the Holy Office in Goa. Special emphasis is given to the inquisitors' different understandings of the reality they ended up labeling gentilidade. It is important to note here that the use of the words 'Gentile(s)' and 'Gentilic' throughout this chapter, when speaking about the populations listed above, reflects identities as they were recognized through such terminology at the time.

Second, this chapter analyzes the Goa Inquisition's procedures to determine precisely what kind of behavior could fall under the label gentilidade and in what way it differed from other categories of transgression. Finally, a comparison between the offence that the inquisitors in Goa came to refer to as gentilidade and behaviors stemming from a non-Christian context in Brazil in the 159 os is established. By focusing on the inquisitorial trial records from the Santidade movement of the previous decade, I will highlight the criteria according to which gentilidade - as understood in Goa — can be considered exceptional in the context of the Portuguese Inquisition.

\section{Lexical Entanglements: The Problem of Gentilidade in the} Goa Inquisition

Established in 1560, the Goa Inquisition was not far away, either in space or time, from the universe of gentilidade. Located on Tiswadi island, the court

8 Resende, “'Da ignorância e rusticidade': os indígenas e a Inquisição na América portuguesa (séculos XVI-XIX)", 101-110. 
functioned in the city that constituted the center of the political and administrative power of the Estado da India. ${ }^{9}$ This territorial base that the Portuguese had conquered in 1510 would only be expanded in 1543 with the incorporation of the territories of Salcete and Bardez. The original nucleus of Tiswadi (with the smaller islands of Divar, Chorão, and Juá) alongside the new provinces formed what became known as the 'Old Conquests'. In this highly porous space, the terra firme as it appears in documents, was to become a constant concern for the Portuguese authorities and the Inquisition itself. The hardening of Portuguese religious policy from 1540 onwards on the island of Tiswadi (extending to the provinces of Salcete and Bardez in the decades that followed), as well as the periodic renewal of repressive measures against the 'Gentilic' customs over the centuries, stimulated the crossing of Christians of local origin (novamente convertidos; cristãos da terra) to the territories of the sultanate of Bijapur, in search of spaces where they could continue to celebrate their rituals. Indeed, when the Inquisition was established in Goa, not only was gentilidade far from being eradicated, but Portuguese domains were not impervious to its influence. ${ }^{10}$

'Gentilidad(e)' is a familiar term in the Portuguese and Spanish languages. Still, it is worth looking at what Iberian Tesoros, Vocabularios, and Diccionarios indicate. Although Sebastián de Covarrubias used the term gentilidad in his 1611 Tesoro, there is no specific entry for it; s. v. "Gentiles", he informs us that these are "the idolaters who had no knowledge of a true God, and worshipped false Gods, and hence gentilidad, paganism"."11 The Diccionario of the Real Academia Española refers to gentilidad as the false religion of the Gentiles or idolaters or, alternatively, the whole and aggregate of the Gentiles. ${ }^{12}$ In this volume, we also find the word gentilismo which is presented simply as being the same as gentilidad. In Raphael Bluteau's Vocabulario Portuguez e Latino, gentilidade is simultaneously "A False Religion of the Gentiles" and "The time, or the place, in which formerly there were \& still today are gentiles". In this same Vocabulario we also find gentilismo, whose meaning is presented to us as

9 On the origins of the Inquisition of Goa see Cunha, A Inquisição no Estado da Índia, and Paiva, "The Inquisition Tribunal in Goa: Why and for What Purpose?", 565-593.

Xavier, A invenção de Goa, 122, 130-131, 170-171. For the notions of "novamente convertido" and "cristão da terra" see also Xavier, "De converso a novamente convertido" and "Conversos and Novamente Convertidos". no tuuieron conocimiento de vn verdadero Dios, y adoraron falsos dioses, y de alli gentilidad, el paganismo". 
"Religion, doctrine, \& rites of the Gentilidade".13 These very succinct definitions seem to admit the rank of "religion" to the whole of the cults and venerations of the Gentiles. This choice of words is far from casual, as it corresponds to the definition of religion found in the Diccionario of the Real Academia Española: "Improperly and abusively, it is also called the worship and veneration that some Nations pay to their false Gods". ${ }^{14}$ There are, therefore, two prevailing definitions for 'gentilidad (e)': on the one hand, that of false religion; on the other hand, that of the collective human reality that underlies the term.

Early Christians employed the term "Gentiles" as a marker of religious differentiation for every person that did not profess the revealed faith of the God of Abraham in any of its forms (Jewish or Christian), usually connoting idolatry. ${ }^{15}$ During the Middle Ages, this basic distinction remained in effect, even as Muslims (Saraceni or Mahometanos) were integrated into the taxonomy of unbelievers. Authors such as Alan of Lille ( $\dagger 1202)$, Thomas Aquinas $(\dagger 1274)$, and Albert the Great $(\dagger 1280)$ tended to integrate them in the broader notion of Gentiles or paganos (pagans), all the while recognizing a distinction to them. ${ }^{16}$ On a Hans Burgkmair engraving from 1508 representing the Triumphant Church, that served as title page for Johannes Stammler's Dialogus de diversarum gencium sectis et mundi religionibus, among the defeated "sects" or "religions" (depicted as women, carrying broken standards, on whose feet lie deposed shields) "Gentilitas" appears separately from "Saracenathur" and "Machometus" (Muslims). ${ }^{17}$ Thus, in this pictorial narrative, "Gentilitas" has equal status to the rest of the expressions of religious infidelity.

Since the 16th century, missionary experiences in America and Asia have played an important role in diversifying the traditional narrative focus on and definition of Gentiles and gentilitas, from its historical sense linked to the Greek-Roman culture to the universe of the peoples that the Europeans contacted during their expansionist endeavors. The former is still the meaning employed by Martín de Azpilcueta when he contrasted the "legisladores de la gentilidad" (legislators from the gentilidad) with the ones from the "Christiandad". 18 Juan de Solórzano Pereira in his Politica Indiana retains both notions:

\footnotetext{
13 VPL, 1713, vol. 4, s. v. Gentilidade and Gentilismo: "Religião, doutrina, \& ritos da Gentilidade".

14 DRAE, 1737, vol. 5, s. v. Religion: "Impropriamente y por abuso, se llama tambien el culto y veneración que tributan algunas Naciones a sus falsos Dioses".

Rubiés, "The concept of a Gentile Civilization in Missionary discourse and its European reception", 118-119.

16 Congar, "Gentilis' et 'Iudaeus' au moyen âge”, 223-224; Evans, Alain of Lille, 127-129; George-Tvrtković, "Deficient Sacraments or Unifying Rites", 107-108.

17 Stammler, Dialogus de diversarum gencium sectis et mundi religionibus.

18 Azpilcueta, Manual de Confessores y Penitentes, 462.
} 
as a side note to his dedication to King Philip IV he specified that Jupiter was "the greatest of all the planets and of the gods of the Gentilidad", while later mentioning the "time of [the American Indians'] infidelity, or gentilidad". 19 In both examples gentilidad seems to be a reality separated by time, i.e., before and after conversion. However, insofar as Solórzano Pereira used the term to encompass the customs, rites, ceremonies, and experiences of the Gentiles, he was responsible for conferring a presentness to it, one that it likely did not enjoy in the centuries prior to the European expansion. ${ }^{20}$

The status of infidelity ascribed to the socio-religious setting of the Indians should constitute an indicator of where in the hierarchy of crimes under the jurisdiction of the Holy Office the crime gentilidade could be located. From the identification of the term as sect and false religion, it could be inferred that a crime of gentilidade would suggest a case of heresy and/or apostasy. Therefore, it would be logical to find it referenced in certain inquisitorial documentation such as the inquisitors' manuals - not necessarily Eimeric's Directorium but, more generally, the handbooks that the inquisitors had at their disposal to guide them in their interrogations for each offence. ${ }^{21}$

Regrettably, the archive of the Goa Inquisition was almost entirely destroyed in the 19th century, with only a collection of nine volumes surviving, composed mostly of correspondence and provisions from the Portuguese inquisitor general. ${ }^{22}$ As an alternative, a comparison with the Inquisition of Lisbon could be made to overcome such gaps. This court also had jurisdiction over a district comprised of vast areas where a large part of the population had recently converted to Christianity and/or had borders that were very permeable to the context of gentilidade such as Brazil or Angola. However, when looking at the handbooks that guided the inquisitors of Lisbon in their procedural work, there is no mention of this kind of offence. ${ }^{23}$ Presumably, in terms of transgression of the rules of law, gentilidade was not a reality that imposed itself on the

19 Solórzano Pereira, Politica Indiana, "Dedicatoria", fn k; lib. 2, cap. XIV, 137.

20 Rubiés, "The concept of a Gentile Civilization in Missionary discourse and its European reception", 113-155.

Surviving handbooks of the Inquisition of Lisbon evince that each tribunal—likely at the request of the inquisitors - prepared guidelines on how to proceed during the interrogations. Those guidelines were, often, structured by typologies of offences. See, for instance, ANTT, Tribunal do Santo Ofício, Inquisição de Lisboa, liv. 73, 75, and 76. Feitler, "O Secreto do tribunal indiano da Inquisição portuguesa", 48-50.

23 In 2009, Célia Tavares had already noticed that what she called "gentilismo" was absent from yet a different type of document, the Regimentos (instructions prepared by the inquisitor general and the deputies of the General Council) of the Portuguese Inquisition. Tavares, "A Inquisição e a Companhia de Jesus diante do 'Gentilismo”, 4. 
Lisbon court to the point of generating specific guidelines to be used in judicial sessions. This is all the more remarkable because the trials conducted by this court included a large number of cases against natives of Brazil and Angola who converted to Catholicism, where the mention of Gentilic ceremonies is expressly recorded.

It is very likely that this textual silence shown in Lisbon, did not occur in Goa. Although the original trial records were lost, a Reportorio (directory) of cases tried between 1561 and 1623 survived. This invaluable document prepared by the promotor (prosecutor) of the Goa Inquisition, João Delgado Figueira, provides very succinct information about each case tried by the court during this period: name of offender, birthplace, socio-religious category, locations to which they were socially bound (by marriage, residence, or function), ${ }^{24}$ name of spouse (if applicable), occupation, description of offence, sentence, and typology of offence. ${ }^{25}$ The inquisitors also sent lists of autos-da-fé to Lisbonsimilar to the relaciones de causas (trial reports) sent from the different tribunals to the Supreme Council in Madrid. However laconic they may be, these types of documents provide ample evidence of trials conducted on charges of gentilidade. Sadly, these lists are inconsecutive, so that an assertion regarding the Goa Inquisition's procedures for the entirety of its activities is not possible.

It is, precisely, in the Reportorio that we first acknowledge the ample use of the category gentilidade to classify a type of religious offence, whose definition is not provided by the document. The emergence of this category in the early 1620 s has not been the object of debate so far. Rather, it was the diversity of offences tried by the court that the inquisitors grouped together under "gentilismo" or "gentilidades" that attracted the attention of scholars. Maria de Jesus dos Mártires Lopes stated that such charges "comprise[d] the various Hindu rites committed by Christians". ${ }^{26}$ These terms, which Lopes recognized as judicial categories current in the 18th century, came to be used, in recent years, as

24 Not to be confused with the place of arrest by the Inquisition. This type of information in the Reportorio indicates the formal place of social affiliation, usually preceded by the statements of "morador em" (resident at), "casado em" (married in: the phrasing in Portuguese indicates the place where the actual marriage took place, which is not necessarily the place where the defendant and his/her spouse reside) or "gancar em" (gaunkar in). For a discussion of this category used by João Delgado Figueira in his Reportorio, see Lourenço, "Macau, porto seguro para os cristãos-novos?", 479-480.

Reportorio Geral de tres mil oitocentos processos, que sam todos os despachados neste Sancto Officio de Goa, \& mais partes da India. BNP, Cód. 203. On this document, see Tavim, "Um inquisidor inquirido"; Feitler, "João Delgado Figueira e o Reportorio da Inquisição de Goa"; Silva, Inquisição e Mestiçagem Cultural no Estado da Índia (1560-1623).

26 According to the author, these included demonic pacts, to invoke or make offerings to the idols, to perform superstitious ceremonies, to work in the construction of temples, to 
broad epistemological categories in their own right, irrespective of the specific charges brought against the defendants ${ }^{27}$. Nevertheless, the question was raised by Bruno Feitler when he pointed out the difficulty of understanding exactly what was characterized as gentilidades due to the loss of the Goa Inquisition trial records. ${ }^{28}$ Authors such as Ricardo Ventura, who also employed the plural form gentilidades, introduced an operative distinction between charges of heresy and apostasy that involved the frequency of "Gentile ceremonies" associated with rites of passage, on the one hand, and demonic pacts, associated with popular healing, divinatory, protective, and agrarian rites, on the other. ${ }^{29}$

Charles Amiel especially emphasized Hinduism as the common denominator of these offences. The author has simultaneously employed the terms "Hinduism" or "crypto-Hinduism" to refer to this impressive volume of cases which, in the Reportorio, constituted $44 \%$ of the total. ${ }^{30}$ Significantly, he never once mentioned the term gentilidade, which means that he incorporated this category under the larger notion of "crypto-Hinduism". ${ }^{31}$ The dilution of gentilidade

cultivate the rice fields of Hindus, as well as "cases of reverting to gentilismo". Lopes, "A Inquisição de Goa na primeira metade de Setecentos”, 129.

27 In her thorough analysis of the Reportorio, Luiza Tonon da Silva identified the following categories: divinations, to worship the devil, to worship pagodes, witchcraft, to consult sorcerers, to consult pagodes, sorcery, gentilidades, idolatry, to idolize the devil with sorceresses, to summon the devil, oblations, covenant with the devil, sacrifice, sacrifice to the devil, sacrifice to pagodes, to become a Gentile, superstition, treasure, and visionary. Silva, Inquisição e Mestiçagem Cultural no Estado da Índia (1560-1623), 74. In the context of Portuguese presence in Asia, pagode simultaneously means temple and idol. Dalgado, Glossário Luso-Asiático, 129-133; Henn, "Shrines of Goa", 2-3.

28 José Alberto Tavim also pointed out that the Inquisition distinguished gentilismo from other realities considered as belonging to the scope of demonic cults. Feitler, "A Inquisição de Goa e os nativos”, 109; Tavim, “'O culto ao diabo' na Inquisição de Goa, segundo o Reportório de João Delgado Figueira (1623)", 274.

29 Ventura, Conversão e conversabilidade, vol. 1, 290-296. Silva also singled out the summaries in the Reportorio that in her understanding presupposed apostasy for the Holy Office. She registered $5^{2}$ occurrences of behaviors described as "to become a gentile" ("se fazer gentio") and "to rebaptize" ("se rebaptizar") which would constitute such an offence. Silva, Inquisição e Mestiçagem Cultural no Estado da Índia, 98.

30 Amiel, "L'Inquisition de Goa", 240. Recently, Luiza Tonon da Silva must have used an analysis grid similar to that of Amiel, since she obtained the same value for a typology of crimes that she called gentilidades. Silva, Inquisição e Mestiçagem Cultural no Estado da Índia (1560-1623), 74 .

31 There is a logic for doing so; on the one hand, the Reportorio registers an impressive number of cases regarding prisoners from local populations accused of gentilidade and other types of offences. On the other hand, the importance that the cases of Judaism and the standardized figure of the "crypto-Jew" as a paradigm of infidelity to the divine majesty have had in the historiography of the Inquisition generated an analytical paradigm that scholars felt could be transposed to other behaviors that would imply an adherence to 
into gentilidades or "crypto-Hinduism" evinces the choice to reunite the diversity of local rites under one category of religious offence in historiography. However, in doing so, it disregards the reasoning behind these classifications, of which gentilidade - in its singular form - was an intentional one.

If we keep to the classifications actually employed in the Reportorio we may notice a change in the institutional attitudes of the court regarding the behavior that Figueira labeled gentilidade over the first 62 years of inquisitorial activity in Goa (see Chart 7.1).

Total of cases on charges of Gentilidade prosecuted by the Inquisition of Goa (1561-1623)

Gentilidade

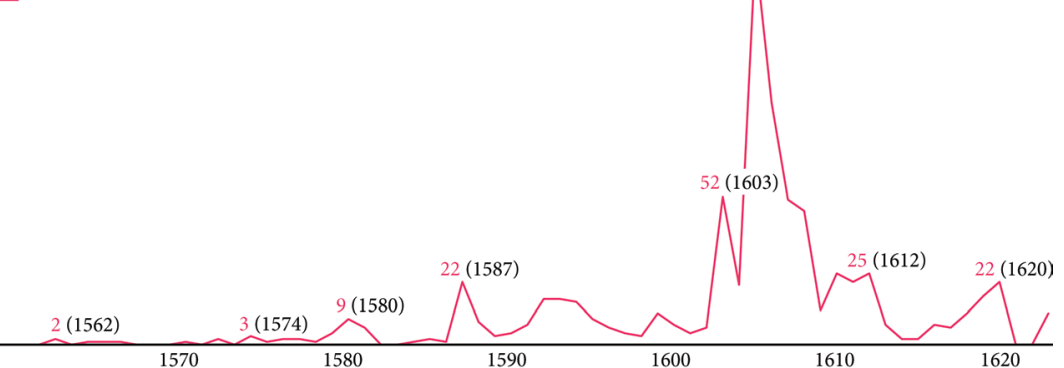

CHART 7.1 Total number of cases tried on charges of "Gentilidade" prosecuted by the Inquisition of Goa $(1561-1623)^{32}$

The data represented in Chart 7.1 does not linearly represent the number of cases regarding offences of gentilidade tried by the Holy Office of Goa. Of the 745 cases reported here, $8.4 \%$ of them are double or triple offences, i.e., the charge of gentilidade occurs alongside others, such as sacrifice, sodomy, sorcery, rebaptism, perjury (falsario), or preventing the expansion of Christianity and the righteous ministry of the Holy Office. In Chart 7.2, double and triple offences have been excluded, thereby including only single offences, and the evolution of offences of gentilidade to those of Judaism and "Moor" (a category used in the Reportorio to denote adherence to Islam or performing its practices) was compared. As can be seen, offences of gentilidade began to increase from the mid-158os, at a time when Inquisitor Rui Sodrinho de Mesquita declared the court's inability to uncover new cases of Judaism: "o judaísmo stá

other systems of beliefs: Amiel, for example, also uses the term "crypto-Mahometism" to mean the inquisitorial category of "mouro" (Moor) or "to become a Moor". Ahmed Boucharb had already employed the similar term "crypto-Muslims" in the late 1980 os to refer to the populations forcibly baptized from Islam into Catholicism in Portugal. Boucharb, Les crypto-musulmans d'origine marocaine et la société portugaise au seizième siècle.

Reportorio Geral de tres mil oitocentos processos, que sam todos os despachados neste Sancto Officio de Goa, BNP, Códice 203. 
quieto", he wrote to the Inquisitor General of Portugal in $1587 \cdot^{33}$ The rise of charges labeled "Moor" had even preceded those of gentilidade at this time. Francisco Bethencourt points out that the power to classify heresies represented, for the Holy Office, a space of statutory affirmation in society by revalidating its position in determining the boundaries of orthodoxy. ${ }^{34}$ The gradual growth of charges of "Moor" and gentilidade after 1585 perhaps represents the adjustment of the tribunal to its new reality, where its social relevance could no longer be dependent upon cases of Judaism, as well as the hardening of the ecclesiastical stance on Gentilic rites and ceremonies following the 1579 revolt of Salcete's inhabitants and the execution of five Jesuits in the village of Cuncolim in $1583 .{ }^{35}$ Particularly in the beginning of the 17 th century, there were moments in the procedural rhythm of the Goa Inquisition, especially between 1603 and 1607, when charges of gentilidade sometimes represented more than half of the cases. It does not seem likely that the inquisitorial handbooks used in Goa-unfortunately, lost forever-kept the same silence on this kind of offence as the ones in Lisbon.

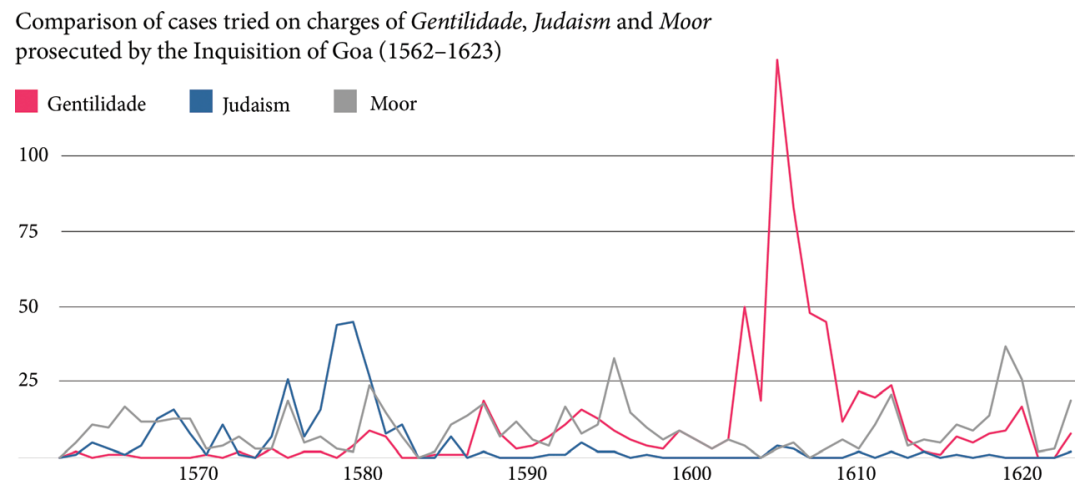

CHART 7.2 Cases tried on charges of "Gentilidade", "Judaism", and "Moor" prosecuted by the Inquisition of Goa $(1561-1623)^{36}$

33 Letter from Rui Sodrinho de Mesquita, Inquisitor of Goa, to the Archduke Albert of Austria, Inquisitor General of Portugal, December 2, 1587, Goa; Baião, A Inquisição de Goa, vol. 2, 119 .

34 Bethencourt, História das Inquisições, 262.

35 On the context of the tensions felt in Salcete in the 1570s and early 1580s, see Aranha, Il Cristianesimo Latino, 146-162.

$36 \quad$ Reportorio Geral de tres mil oitocentos processos, que sam todos os despachados neste Sancto Officio de Goa, BNP, Códice 203. This chart indicates only the cases where the defendants were not subjected to a second or third accusation. 
The fact that the Portuguese employed the terms gentilismo and gentilidade to refer to religions beyond Judaism and Islam also raises difficulties when trying to achieve a definition of gentilidade as a religious offence. ${ }^{37}$ If it is taken to be an equivalent to "crypto-Hinduism", how should charges against defendants that lived in locations far from Hindu contexts be interpreted? ${ }^{38}$ At the same time, is it not possible for those who converted from the Gentiles of Brazil or Angola to also have committed crimes of gentilidade from the point of view of an inquisitor?

Considering the absence of the handbooks used in Goa, and without being able to benefit from the diverse array of the original proceedings followed by this court, the task of defining gentilidade as a behavior under the jurisdiction of the Holy Office is a challenging one. The identification of gentilidade with one of the most used categories of offence in Spanish America, that of idolatry, poses a methodological problem. The fact that the Goa Inquisition and its activities remained a marginalized subject until the early 2ooos explains why gentilidade as a judicial category was never truly addressed on its own terms. In recent years, scholars who addressed the Inquisition of Goa's actions against religious offences stemming from local customs showed a preference for analyzing the issue from the point of view of idolatry. ${ }^{39}$ This epistemological framework is, of course, in accordance with both theological, missionary, and legal discourse of the time, insofar as it meant diverting worship-which was due to God alone - to things or false Gods. ${ }^{40}$ However, when looking at the categories used in the Reportorio, it is noteworthy that idolatry is practically absent from Figueira's choices of classification, something that is quite puzzling if one considers the abundance in which idolatry is mentioned in missionary reports to refer to the local population's ritual practices. According

37 This paper will also not address the issue on the reified character of Hinduism nor the appropriateness of referring to local populations' beliefs under Portuguese rule as "Hinduism". The Portuguese employed terms such as gentilismo and gentilidade to refer to the beliefs and rituals of non-Muslims and non-Jews and it is this conceptual framework that will be analyzed here. See, on the epistemological difference between Gentilismo and Hinduism, Rubiés, "Reassessing the 'Discovery of Hinduism", 114-119.

38 In 1591, Constantino Farinha, a merchant living in Macau, China, was tried on charges of gentilidade. Since it is known that Farinha lived in Siam for a part of his life, Buddhism rather than Hinduism seems to be the obvious background for the practices tried by the Inquisition. Reportorio [...], fol. 22or; Lourenço, A Articulação da Periferia, 155.

Xavier, A Invenção de Goa, 326; Marcocci, A Consciência de um Império, 391. For Burkardt, in Goa the concept of idolatry came to be equated with that of superstition on account of the association between the practices of Gentiles of India and the superstitions of ancient paganism. Burkardt, "Superstizione".

For a broad analysis of the term, see Barbu, "Idolatry' and Religious Diversity", 39-50. 
to the Reportorio, there is but one case unequivocally identified as idolatry (curiously pertaining to an Old Christian, a Portuguese person from Lisbon, for making a solemn oath before the idols); one case of an Armenian "idolizing the devil with spells", which has no classification; and one case of a man born in Goa (although it is not known whether he was an Old Christian or a cristão da terra) idolizing the pagodes and making offerings to them, which Figueira classified as "sacrifices". ${ }^{41}$

The issue of classification of religious offences by the Goa Inquisition grows ever more complex if we consider other sources that refer to the defendant's actions. In a list of defendants tried in 1609 and 1610, the inquisitors of Goa prepared a summary of their offences and the resolutions of the court to send to the higher inquisitorial authorities in Lisbon. This is a most unique list, not only because it is the oldest surviving document of this type, but also because it is the only one that was prepared during the period covered by the Reportorio. This provides an extraordinary opportunity to compare the choices of classification employed by the compilers of the list with Figueira's. ${ }^{42}$ And, as it turns out, the 1609-10 list provides no less than six cases explicitly described as "offences of idolatry", all of which were described by Figueira as cases of gentilidade in $1623 .{ }^{43}$

As can be seen from these examples, not only is there a diversity in deviant behavior that does not come together in unequivocal criminal categories, but also the ministers of the Holy Office themselves did not display the same preferences regarding the classification of the same offences over a very short span of time. The divergence between the categories employed by the inquisitors of 1609-10 and Figueira in 1623 reveals how much the Portuguese legal, missionary, and inquisitorial context of dealing with or repressing gentilismo or gentilidade imposed itself in different ways on the intellectual attitudes of the Holy Office's members on the subject (some of whom had recently arrived from Europe). This presents an additional difficulty when trying to understand what exactly constituted a crime of gentilidade.

$41 \quad$ Reportorio [...], fols. 194V, 293v, 583r. The term cristão da terra literally translates to "Christian of the land", i.e., a person indigenous to the territory, or Asia broadly speaking, converted to Catholicism.

42 By the time Figueira began his work as prosecutor of the Inquisition of Goa in late 1617, both inquisitors that were in office in 1609-1610, Jorge Ferreira and Gonçalo da Silva, had ceased their functions in the court.

43 List of individuals tried by the Inquisition of Goa in the year 1609 and 1610, undated. Antr, Tribunal do Santo Ofício, Conselho Geral do Santo Ofício, liv. 369, fols. 23v, 26v-27. The cases specifically referred to as offences of idolatry are those of João de Figueiredo (regarding a previous trial), Filipe Rodrigues, Pêro de Oliveira, Domingos Fernandes, Domingos da Cunha, and Simão Furtado. 


\section{Constructing 'actos de gentilidade' as a Religious Offence}

It is possible to find a concrete example of the methodological difficulties regarding the definition of this concept in one of the few surviving recorded procedures against a cristão da terra. In 1592, Francisco Rangel, a gaunkar ${ }^{44}$ of Corlim, was accused of and sentenced for gentilidade. In 1603 he was again brought before the Inquisition. According to the Reportorio, the same verdict of gentilidade was passed on both occasions. ${ }^{45}$ In his second trial, Rangel was accused of having sacrificed rams to a pagode (which here must be understood as a deity/idol) or — as it appears in another testimony against him — to a diabo (devil), to ensure the protection of the várzea (rice field) they were planting. ${ }^{46}$ Rangel confessed to having done this along with other gancares because it was the condition imposed by Domingos de Mesquita, a recently elected camotim-responsible for the vigilance of the valados (dykes/sluice gates) with which the várzeas were fenced so that saltwater could not enter. ${ }^{47}$

From the interrogation and accusation, it is clear that Rangel was being questioned on the possibility of having made a demonic pact, because the inquisitor asked him if he believed that the pagode or diabo had the power to protect the várzea and if he was aware that it was a sin to kill the rams for the sake of the devil. ${ }^{48}$ Afterwards, the inquisitor asked him the following question, which warrants being reproduced in full:

Asked if he, the defendant, believed in the Pagode Rauelanato [Ravalnath] as he did the first time he was tried by this Board, he said that since that time he no longer believed in said Pagode, nor in any other of the Gentiles, because he knew very well that everything was wind [sic., hollow $] .49$

44 A gancar (gaunkar) was the male member of the vangad (clan) who, after coming of age (c. 12-18 years old) belonged to the councils of the rural communities (gaunkari). See Souza, Goa Medieval, 6o; Dalgado, Glossário Luso-Asiático, vol. 1, 416-417; and Xavier (Chapter 2) in this volume.

45 Reportorio [...], fols. $316 \mathrm{r}, 327 \mathrm{v}$.

46 Procedures against Francisco Rangel by the Inquisition of Goa, 16o3-16o5. ANTT, Tribunal do Santo Oficio, Inquisição de Lisboa, no. 8916, fols. 2r-6v.

47 Procedures against Francisco Rangel by the Inquisition of Goa, 1603-1605. ANTT, Tribunal do Santo Ofício, Inquisição de Lisboa, no. 8916, fol. 11r. Dalgado, Glossário Luso-Asiático, vol. 1, 192-193.

48 Procedures against Francisco Rangel by the Inquisition of Goa, 1603-16o5. ANTT, Tribunal do Santo Ofício, Inquisição de Lisboa, no. 8916, fol. 14r.

49 Procedures against Francisco Rangel by the Inquisition of Goa, 1603-1605. ANTT, Tribunal do Santo Ofício, Inquisição de Lisboa, no. 8916, fol. $14 \mathrm{r}$. 
Later, pressed to declare his tenção (intention; will) in making the sacrifices and sumbaias (reverential greetings) ${ }^{50}$ to the pagode (in this case, an idol) and whether he ever believed it was God, Rangel said that it was customary to offer a ram to the pagode in his village, but that he never saw it as God nor did he believe in it after he was reconciled with the Catholic faith. If he had committed such acts, he stressed, it was because he feared that the devils/pagodes might come and destroy the fence and the novidade (new crops). Furthermore, he emphasized that he did not entrust (encomendava) himself to the pagode in his house nor did he practice Gentilic ceremonies. ${ }^{51}$

But, above all, what the Inquisition could not prove in this case was the coincidence between the charges of 1592 and those of 1603, which would suggest a case of relapsia (relapse) and a second accusation of gentilidade. As a result, the majority of the Goa Inquisition's board determined that the acts were not heretical and differed from the previous ones and that evidence was insufficient to suggest a second incidence of the same offences. ${ }^{52}$ Nevertheless, one dissenting voice argued that the defendant should be delivered to the secular authorities for execution due to him relapsing. Deputy Fr. Domingos da Trindade opposed the prevailing opinion that Rangel's poor indoctrination, natural inclination, communication with the Gentiles of the surrounding areas, and material interest of cristãos da terra in the new crops should excuse the presumption of ill will (má vontade) on his part. On the contrary, the fact that Rangel had committed many different acts for many years was proof of his ill will, Trindade argued. ${ }^{53}$ The deputy's understanding was that insofar as Rangel committed the offences with ill will, thus, aware of his wrongdoing, he should be tried as a relapse. It was due to this disagreement that a copy of the trial records was sent to the General Council of the Holy Office in Portugal for analysis, hence its existence today. The Council replied in 1605, validating the decision of the majority of the board. ${ }^{54}$ As pointed out by Giuseppe Marcocci, the

50 From the Malay sembahyang, composed from the root words sembah (worship) and yang (divinity). The Portuguese in Asia used the word as a synonym of "courtesy", signifying the reverential greetings and honors bestowed on a person or an idol. See Wilkinson, s.v. "sembahyang", 405; Dalgado, Glossário Luso-Asiático, vol. 2, "Sumbaia, zumbaia", 326-328. Procedures against Francisco Rangel by the Inquisition of Goa, 1603-1605. ANTT, Tribunal do Santo Ofício, Inquisição de Lisboa, no. 8916, fols. 21r-21v. Procedures against Francisco Rangel by the Inquisition of Goa, 1603-1605. ANTT, Tribunal do Santo Ofício, Inquisição de Lisboa, no. 8916, fol. 22. Procedures against Francisco Rangel by the Inquisition of Goa, 1603-1605. ANTT, Tribunal do Santo Ofício, Inquisição de Lisboa, no. 8916, fols. 22r-22v.

54 Procedures against Francisco Rangel by the Inquisition of Goa, 1603-1605. ANTT, Tribunal do Santo Ofício, Inquisição de Lisboa, no. 8916, fol. 23. See, also Marcocci and Paiva, História da Inquisição Portuguesa, 115. 
issue in such cases "was how to find a common opinion on the exact boundary between rites and customs with religious meaning, and those without". 55

So, even though the records of the first trial of Rangel were lost, it seems clear that the accusation of gentilidade, as registered by the Reportorio, implied the identification of a given supernatural being with a deity or, to be more exact, with an equivalent to God-something that presupposed belief in a divine being and the act of "entrusting oneself" to it or, if we follow an 18th-century definition, "giving oneself and resigning oneself into the hands of another, and trusting in their protection and will". ${ }^{56}$ It was this trust and belief in the divine otherness that, for the Inquisition, constituted a crime with a whole range of other consequences.

As can be seen, in addition to the diversity of practices that appear to signify the same offence, an analysis of the actions of the Holy Office of Goa is also made difficult by the choices of the compiler at the time of categorization. For instance, although Figueira categorized both offences committed by Rangel as gentilidade, it should be noted that the inquisitors' ruling of 1603 makes no mention of this term. The issue here concerns what can be defined as gentilidade. If we consider that officers employed in the service of the Holy Office shared a common lexicon necessary to the administration of justice according to a rule of law, the differences of categorization in 1610 and 1623 should reflect qualitative changes in the understanding of the phenomena. Precisely, in order to comprehend these changes, it must first be determined which features in the offenders' behaviors justified being classified under the category gentilidade, as well as the reasoning behind it according to inquisitorial procedures.

When, in the early 1580s, the inquisitors of Goa and the General Council of the Holy Office began to appreciate in greater depth the cristãos da terra's propensity to revert to the practice of Gentilic rituals, this problem was addressed alongside the broader issue of apostasy in the territories surrounding Goa, Bardez, and Salcete. ${ }^{57}$ In 1584, the deputies of the General Council clarified to

55 Marcocci, “Rites and Inquisition”, 151.

56 DRAE, 1732, t. 3, s. v. Encomendarse: "entregarse y resignarse en mano de otro, y fiarse de su amparo y voluntad".

57 In 1579, an ecclesiastical conference (junta) which brought together the Bishop of Cochin (acting as governor of the Goa archbishopric and elected Archbishop), the prelates of the Dominicans and the Franciscans, and other members of their orders (the Jesuits provided a resolution at another time) issued a resolution against sanctioning certain rites and ceremonies to the non-Christianized populations of Salcete. The conference reached a resolution that did not meet the expectations of either side, despite the undergoing revolt of Salcete's inhabitants. Ultimately, this decision received the support of the new monarch, Philip I (II of Spain) who, in 1581, prohibited the existence of pagodes and Gentile 
the Goa Inquisition the appropriate procedure to follow in cases where Portuguese, mestiços, and cristãos da terra "went to the Moors or to the Gentiles and there joined their sects and then came back to the Holy Office to reconcile themselves, confessing how they departed from the faith of our Lord Jesus Christ and believed in the said sects" ${ }^{58}$ In the same document, "to change to their sects" is equivalent to being a renegade or having committed infidelity. Accordingly, the inquisitors were told to investigate the causes for which the defendants committed "Moor or Gentile acts" (autos de mouro ou gentio), i.e., analyze their "will" (tenção)..$^{59}$

As can be appreciated, the type of crime under discussion involves an act of infidelity against the divine majesty which presupposes a rupture of belief in the Catholic faith, expressed by adherence to an alternative - and therefore false and erroneous-doctrine. For the purposes of inquisitorial justice, this change or transition can be objectively identified in the public behavior of the defendant, from their choice of attire (to dress in the manner of a "Moor" or a Gentile) to the performance of certain rites and rituals. Determining the intention behind these exterior acts is, therefore, paramount to proving infidelity.

and Muslim public rites and ceremonies in his territories. The matter had been a concern of the First Provincial Council of Goa (1567), but not of the Second Provincial Council (1575), who did not issue any decrees on the rites of the Gentiles. In 1585, however, the first decrees of the Third Provincial Council concerning conversion readily addressed the problems arising from idolatry. The 1579 resolution appears to have been based on the anonymous allegation of "a Friar of much zeal" whose identity we ignore. This allegation was incorporated into Francisco de Sousa's Oriente Conquistado a Jesu Christo in 1710. The author, however, misplaces the year of the junta, wrongfully stating that it took place in 1576. The 1579 letter of the inquisitor Bartolomeu da Fonseca confirms that the junta took place during that year. See: "Sententia superiorum ecclesiasticorum Indiæ et consultorum de liceitate rituum ethnicorum", April 9, 1579, in Goa, in DI, vol. 11 (1970), 562-569; Charter of King Philip I of Portugal, of 25 February 1581, in Elvas, in O Livro do 'Pai dos Cristãos', 69; Letter of Bartolomeu da Fonseca, Inquisitor of Goa, to Cardinal Henrique, King of Portugal and Inquisitor General, December 1, 1579, in Goa, in Baião, A Inquisição de Goa, vol. 2, 78-79; Francisco de Sousa, Oriente Conquistado, vol. 2, 136-143. The anonymous allegation was analyzed in detail by Paolo Aranha in Il Cristianesimo Latino, 146-151; For a general appreciation of the Provincial Councils' decrees on the matter of conversion see, Aranha, Il Cristianesimo Latino, 164-170; Faria, "Os concílios provinciais de Goa", 233-237. See also Faria chapter (Chapter 4) in this volume.

$5^{8}$ Reply from the General Council of the Holy Office to the memorandum by André Fernandes, acting inquisitor of Goa, undated (c. March 1584). ANTT, Tribunal do Santo Ofício, Conselho Geral do Santo Ofício, liv. 311, fol. 91r.

59 Reply from the General Council of the Holy Office to the memorandum by André Fernandes, acting inquisitor of Goa, undated (c. March 1584). ANTT, Tribunal do Santo Ofício, Conselho Geral do Santo Ofício, liv. 311, fol. gir. 
This much is clear from a 16th-century trial record that has fortunately survived. Lopo Álvares was tried on charges of gentilidade in 1594, according to the Reportorio ${ }^{60}$ His trial record was copied by order of Inquisitor António de Barros and sent to the General Council of the Holy Office for analysis. ${ }^{61}$ Álvares was a cristão da terra who had been baptized just two years before. The inquisitor suspected apostasy due to his absence from Catholic territory a mere three months after baptism, as well as to his change of attire. Thus, his interrogation was aimed at ascertaining that possibility. In his first session, Barros admonished Álvares to provide a complete confession of his offences, confirming whether "he shared the belief of the law of the Gentiles". ${ }^{2} \mathrm{He}$ further inquired whether he believed that the Gentiles could be saved if they followed the "law of their sect",63 as well as if when entering a pagode (temple) he removed his shoes "in the manner of the Gentiles", if he prayed and did any "sumbaia", ${ }^{4}$ or if he venerated any pagode (idol). ${ }^{65}$ Álvares denied having ever done so, stating on more than one occasion that if he "wished to become Gentile again he would have taken up caste". ${ }^{66}$ His response, which referred to a process of purification well-known to Portuguese ecclesiastical authorities and regarded as apostasy, reveals the consensus between the two people involved in the interrogation - that the practices and rituals mentioned by Barros were binding to the "law of the Gentiles" and that to embrace them was to break away from Catholicism. Ultimately, the Inquisition could only prove that Álvares wore a turban or a pagri (touca) and a tunic (túnica) among Muslims and Gentiles,

60 Reportorio [...], fol. $453 \mathrm{v}$.

61 Procedures against Lopo Álvares by the Inquisition of Goa, 1594. ANTT, Tribunal do Santo Ofício, Inquisição de Lisboa, no. 12738, fol. 1r. Silva describes the case in detail. See Silva, Inquisição e Mestiçagem Cultural no Estado da Índia (1560-1623), 146-153.

62 Procedures against Lopo Álvares by the Inquisition of Goa, 1594. ANTT, Tribunal do Santo Ofício, Inquisição de Lisboa, no. 12738, fol. 3 v.

63 Procedures against Lopo Álvares by the Inquisition of Goa, 1594. ANTT, Tribunal do Santo Ofício, Inquisição de Lisboa, no. 12738 , fol. 4 r.

64 Procedures against Lopo Álvares by the Inquisition of Goa, 1594. ANTT, Tribunal do Santo Ofício, Inquisição de Lisboa, no. 12738, fol. $4 \mathrm{r}$.

65 Procedures against Lopo Álvares by the Inquisition of Goa, 1594. ANTT, Tribunal do Santo Ofício, Inquisição de Lisboa, no. 12738, fol. 4 v.

66 Procedures against Lopo Álvares by the Inquisition of Goa, 1594. ANTT, Tribunal do Santo Ofício, Inquisição de Lisboa, no. 12738, fol. 4r. Ines Županov and R. Po-Chia Hsia employed the less literal but more accurate translation of "return to caste" when analyzing the official declaration of the Third Ecclesiastical Council of Goa that described how new converts left Catholic territory to perform ceremonies and consume foul drinks to purify themselves from the food they ate as Catholics. Županov and Hsia, "Reception of Hinduism and Buddhism", 577; Third Ecclesiastical Council of Goa, 1585, Decree 7, Archivo Portuguez Oriental, fasc. 4 (1862), 125-126. See, also Faria, “De réus a colaboradores", 171-172. 
disregarded Friday fasts, and washed his body in the fashion of the Gentiles while living among them. ${ }^{67}$ Figueira's choice to catalogue this case as one of gentilidade was thus not based on the offences that the Inquisition was able to prove according to behavior, but on the presumed charges and general direction of the interrogation.

Despite the apparently straightforward identification between gentilidade and apostasy ("to become a Gentile"68), the unique social and ritual features that the Goa Inquisition had to pass judgment on made legal communication inside the different organisms of the Portuguese inquisitorial system difficult. In 1596, the General Council of the Holy Office revealed its lack of expertise in interpreting cases involving rites and ceremonies specific to Asia. In that year, its deputies requested the inquisitors of Goa to clarify the usage of some "peculiar terms such as 'to take up caste' or 'make sumbaia' and other similar ones" so that they could be understood in Lisbon. ${ }^{69}$ The request reveals the conceptual distance between the Holy Office of Goa and the General Council, to the extent that lexical specificity could prevent a sound comprehension of the offenders' behaviors. Nevertheless, the need for clarification was of paramount importance for the correct exercise of inquisitorial justice because, as will be shown, according to the inquisitors' understanding, "Gentile acts" played a concrete role in expressing devotion to deities of the gentilidade. It was, therefore, against specific "Gentile acts" that the intention of a defendant should be scrutinized.

By 16o6, the inquisitors of Goa were referring to the offences perpetrated by the cristãos da terra as "acts of gentilidade", meaning a form of behavior originating in that particular context. ${ }^{70}$ In the following year, those very same inquisitors - the ones who later developed the 1610 list — spoke of such actions as the result of idolatry. ${ }^{71}$ As discussed, this document categorized as

67 Procedures against Lopo Álvares by the Inquisition of Goa, 1594. ANTT, Tribunal do Santo Ofício, Inquisição de Lisboa, no. 12738, fols. $6 \mathrm{r}-6 \mathrm{v}$.

68 This expression ("se fazer gentio") appears in several of the Reportorio's summaries regarding offences by gentilidade. The earliest use of this expression on the Reportorio occurred in the record of one António of Gujarati origin who had been baptized in adulthood. He was tried in 1586 by Inquisitor Rui Sodrinho de Mesquita precisely "for becoming a Gentile". Reportorio [...], fol. 114r.

69 Ruling of the General Council of the Holy Office regarding the list of individuals sentenced by the Goa Inquisition in 1594, [March 16] 1596. ANTT, Tribunal do Santo Ofício, Conselho Geral do Santo Ofício, liv. 10o, fol. 78. See Faria, "De réus a colaboradores", 169.

70 Letter from the inquisitors of Goa to D. Pedro de Castilho, Inquisitor General of Portugal, December 20, 16o6, Goa. Baião, A Inquisição de Goa, vol. 2, 343 .

71 Letter from the inquisitors of Goa to D. Pedro de Castilho, Inquisitor General of Portugal, December 24, 1607, Goa. Baião, A Inquisição de Goa, vol. 2, 355 . 
idolatry what Figueira labeled gentilidade, which means that, in a very short span of time, the same institution listed the same behavior under two different categories of offence. Moreover, the list mentions a variety of other individuals whose offences were not described in the same manner. Aside from idolatry, the inquisitors registered offences that included the performance of reverential greetings to idols, as well as keeping with the superstitions of the Gentiles, and turning into a Gentile. ${ }^{72}$ What is interesting here is that, while Figueira predominantly labeled many of these offences as gentilidade, he also chose different categories (such as "sacrifices" or "offerings to the pagodes") to label offences that were considered identical for the compilers of the 1610 list. A systematic study of Figueira's categorization of offences has yet to be undertaken by scholars but, without being able to access the actual records, what prompted him to resort to different classifications for the same types of behavior may never be fully ascertained. Nevertheless, what seems to be certain is that, by 1623 , the prosecutor understood that a variety of actions could fall under the label gentilidade, as long as the defendants could be questioned on their will.

An incident that occurred in the 18th century illustrates in a perceptible way the fine line between gentilidade and other behaviors that fell outside this category. In 1736, the Viceroy of India wrote a letter to the King of Portugal referring to a dispute between the chancellor of the Estado da India and the Inquisition of Goa. Following the publication of an edict by the inquisitors that prohibited a wide range of practices carried out by local Christians, the chancellor protested before the viceroy, claiming that the inquisitors had overstepped their jurisdiction. The viceroy then proceeded to inform the king that the decision regarding the edict had been coordinated between himself and the Goa Inquisition. His letter summarizes what, in essence, was the crux of the matter in relation to the Gentilic customs:

The Board of the Holy Office represented to me, through one of its inquisitors, that it had determined to publish an Edict against many customs, which were observed in all these lands, derived from gentilidade, of which experience had shown many to be idolatrous; and although in most

These included "to make sumbaia" as unto an idol, to claim to be an idol and to accept reverence for it, "to make sumbaia" to an idol, to make offerings to an idol, to keep the Gentilic superstitions, to go to the house of an idol and ask for his favor, to make donations to the idols, to become a Gentile and use their attire, as well as to break from the Catholic faith and adhere to the "sect" of the Gentiles. List of individuals tried by the Inquisition of Goa in the year 1609 and 1610, undated. ANTT, Tribunal do Santo Ofício, Conselho Geral do Santo Ofício, liv. 369, fols. 20, 27-28, 3ov-31v, 33v-34v, 35v. 
people who practiced them there was no intention (espirito) of infidelity, in many others, especially in the humblest people, their observance was always with regard to gentilismo; because of this the Board [of the Inquisition] did not doubt that it had jurisdiction to prohibit them, but seeing as there were many that had been allowed for a long time, and in some, who seemed merely political, [to the point that] there was no suspicion of its inconveniences, except amongst the Ministers of the same Board, who had examined them, it seemed to him [the inquisitor] not only that their prohibition required my approval, but also that once the prohibition was published by the Edict of the inquisitors, that I validate it with a charter. ${ }^{73}$

If we read the document carefully, we can see that the Inquisition is walking on quicksand. The simple fact that it needed to consult the viceroy's opinion on this matter suggests that these were a variety of behaviors that had not been regarded as having a necessarily religious value. What seems to be at stake is precisely whether it is possible to separate the "political", i.e. non-religious, side of these traditions from their Gentile context and, consequently, from their apparent devotional meaning. For all intents and purposes, this meant that the practice of such customs had to be scrutinized by the court and clarified in terms of the notion or opinion that the supposed perpetrator held about it. ${ }^{74}$ As is transparently evident from the letter, the inquisitors' main concern was how many of these customs might lead to adherence to a belief, law, or sect, in short, to gentilidade or gentilismo, or, as the text says, to an attitude of infidelity towards the divine majesty of God. Irrespective of the many kinds of customs "derived from gentilidade", the text reveals that what separated a religious offence perpetrated with a "spirit of infidelity" from other types of crimes was notion, opinion, and belief. ${ }^{75}$

As suggested by the trial of Rangel, as well as other entries in the Reportorio, the crime of gentilidade certainly concealed a diversity of ceremonial or ritual realities. In fact, it is very possible that underneath this classification lay many of the social or cultural circumstances mentioned in Rangel's trial alongside an unequal expression of the intentions, opinions, or notions declared by the

73 Letter from Pedro Mascarenhas, Viceroy of India, to D. João v, King of Portugal, December 29, 1736, Goa. Rivara, Ensaio Historico da Lingua Concani, 368. Emphasis added.

74 The issue of the awareness of crime on the part of converted populations is addressed in the context of New Spain, inter alia, in Lara Cisneros, ¿Ignorancia invencible?, 83 et seq.

75 Leaning on Erving Goffman, Pierre Bourdieu, and Michel Foucault, Rowena Robinson provides another analysis of this edict, seeing in it an instrument of deculturation aimed at creating attitudes of internalized discipline that would detach the individuals from their local ('pagan') background. Robinson, “Taboo or Veiled Consent?", 2427-2428. 
defendants over the course of their interrogation. As noted by Délio de Mendonça, relapses cannot be reduced to "deliberate, planned and uncommon happenings". ${ }^{76}$ All this diversity in attitudes, intentions, or group pressures eventually came to the fore when facing the Inquisition, molding testimonies in unexpected ways, particularly when faced with linguistic adversities, as Rangel was, having his session conducted with recourse to an interpreter. ${ }^{77}$

What does seem clear is that in the inquisitors' eyes gentilidade suggested a crime that presupposed the return, precisely, to that homonymous universe, to a community or system of beliefs parallel to Catholicism, which placed that transgression alongside the crimes of heresy and apostasy, such as those of Judaism, "Moor" or "Lutheran". This is evident from the notion of tomar casta in Álvares' trial as something that was equal to "becoming Gentile again". It is also suggested in a questionnaire sent by the inquisitors of Goa to which the General Council of the Holy Office replied in 1636. In this document, in which the judges expressed 25 doubts about the court's procedures, the first question addressed what they said was estilo (custom) in Goa "not to accuse the cristãos da terra based on tenção, [even when it was] certified by witnesses or by [the defendants'] confessions of Gentilic rites and ceremonies". ${ }^{78}$ The inquisitors had realized that, by subjecting these defendants to torture, they had obtained confessions attesting to "the will, and belief with all the circumstances, required by law". ${ }^{79}$ As such, owing to the "quality of the ceremonies and rites" and to the "propensity to follow the Gentile sect in everything", the inquisitors felt assured of the veracity of the confessions.

The language used in this question is of no minor importance, as it frames the typology of offence under consideration. On the one hand, the emphasis given to tenção and crença (belief) is significant, since they are precisely the

76 Mendonça, Conversions and Citizenry, 298. For a critique of rationalized and materialistic understandings of conversion under Portuguese rule, see Aranha, "Early Modern Asian Catholicism and European Colonialism", 289-291.

77 The issue of the credibility of inquisitorial testimonies has been the object of much debate, especially among scholars focusing on the religiosity of New Christians. The achievements of this debate have yet to be applied to the extant testimonies of the cristãos da terra. See H. P. Salomon, "Les procès de l'Inquisition Portugaise"; Eberenz and De la Torre, Conversaciones estrechamente vigiladas.

78 Questions addressed to the General Council of the Holy Office by the inquisitors of Goa, answered in 1636. BNRJ, Inquisição de Goa, 25,1,004, no. 43, fol. 106r. We know from a similar reply in 1634 from the Inquisitor General Francisco de Castro that the question had already been posed to the inquisitorial authorities in Lisbon. See Marcocci, "Rites and Inquisition", 145 .

79 Questions addressed to the General Council of the Holy Office by the inquisitors of Goa, answered in 1636. BNRJ, Inquisição de Goa, 25,1,004, no. 043, fol. 106r. 
criteria that allow a crime to be considered heretical. ${ }^{80}$ Similarly, the reference to sect is not by chance. In the judicial context of the Holy Office, the word sect is used to refer to a variety of collectives that profess the same belief system (in accordance, moreover, with its common meaning). ${ }^{81}$ Among those who belong to sects are Luther's followers, the "Mohammedans", the alumbrados, the sorcerers, the Freemasons, and the idolaters. ${ }^{82}$ The inquisitors themselves did not fail to mention in their letter to the viceroy, when they sent him the edict, that the actions included therein were "the same as those of the Gentilic sect". 83 Therefore, the Gentiles, too, could be framed among the groups known as sects.

"Rites" and "ceremonies" were also objective criteria for warranting a charge of gentilidade. However, as we have seen from Rangel's case, the diversity of ceremonies held in a local context from which to infer such an offence couldand indeed did - generate differences of understanding within the Goa court. It was therefore important to attend to the "quality" of the rite or ceremony.

$80 \quad$ Nicolau Eimeric $(\dagger 1399)$ stated in his Directorium inquisitorum that belief (credentia) in error and obstinacy of will (voluntas) were the two conditions required to classify someone as a heretic: "quod de tali errore credendo, habeat pertinaciam in voluntate". The role of choice (electio) and consent (assensus) had already been emphasized by Aquinas in order to determine partial or full withdrawal from Christ. In the 17 th century, theologians such as Tomás Sánchez (1610) inherited the notion that heresy implied a voluntary and conscious adherence to an error when he discussed how will, obstinacy (pertinacia), and consent (assensus) were necessary to define someone as heretic: "Est error intellectus voluntarius, contra aliquem fidei veritatem, cum pertinacia assertus ab eo, qui fidem recipit. Dicitur error intellectus, id est, assensus falsus intellectus". Aquinas, Summa Theologice, II-II, quæst. 11, art. 1; Eimeric, Directorium Inquisitorum, part 2, quæst. 32, 319; Sánchez, Opus Morale, lib. 2, c. 7, no. 1, 110.

81 The entry "secte" in the Encyclopedie of Diderot and D'Alembert, signed by D.J. (Chevalier Louis de Jaucourt), recognizes the more neutral nature of the word inasmuch as it refers to a group following opinions or maxims originating from a particular person, be it "docteur ou maître particulier". However, he emphasized its proximity to the Greek word

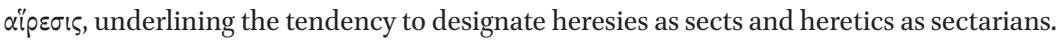
The prevailing sense is thus one of false opinion. Viewed at https://artflsrvo3.uchicago. edu/philologic4/encyclopedien117/navigate/14/4801/ (January 12, 2020).

82 In 1728 and 1729, several individuals from São João da Pesqueira, Ranhados, Poço do Canto, and Souto de Penedono, in the district of the Coimbra Inquisition were charged with idolatry, following their contact with Fr. António Guilherme Hebre de Loureiro. Their sentences explicitly mention their acceptance of the "infernais, e abominaueis erros, e diabolica çeita que comessou á leuantar o Padre Antonio Guilherme Hebre de Loureiro". Procedures against Luísa da Fonseca by the Inquisition of Coimbra, 1728. ANTT, Tribunal do Santo Ofício, Inquisição de Coimbra, no. 7339.

83 Letter from the inquisitors of Goa to Pedro Mascarenhas, Viceroy of India, April 18, 1736, Goa. Rivara, Ensaio Historico da Lingua Concani, 369 . 
Not every practice could warrant an accusation that implied adherence to the secta gentilica, but only, as is understood from the 1636 document, those ceremonies and rites that are protestativas (declarative) of the sect, like sumbaias: "which involve the greatest act of worship of the pagodes, which among the Gentiles are sacrifices of fire, blood, or any other, because they intend to give them honor and veneration as to God; aside from these there are many other superstitions and rites, which do not induce so effective a presumption, in which the ancient custom can be preserved, like going to the houses of the pagodes, without making them sumbaias, attending their feasts and dances, and others of this quality." 84

This text provides the criteria by which an inquisitor should determine an accusation on the grounds of gentilidade: Only those acts that manifested "worship", "honor and veneration as to God" to the pagodes, specifically, sumbaias and sacrifices. These were the acts that, as we read from the response of the General Council, were considered "protestativos e indicativos violentamente da sua secta", that is, as emphatically revealing a statement and indication of adhering to a belief system centered around the idols. ${ }^{85}$ Significantly, during the trial of Álvares, Barros asked him if he had embraced some of these practices.

The dividing line separating acts that denote adherence to another belief organized in a sect from those that did not was thus adapted to the Asian universe from the legal conceptions of heresy and from the judicial procedures destined to try it, systematized for the Portuguese Inquisition through the Regimentos of $155^{2}$ and 1613 . According to the 1636 document, this delimitation had been the practice of the Goa court since the end of the 16th century and beginning of the 17 th century. It was this legal framework that Figueira had in mind when he grouped the diversity of ritual declarative behaviors originating in the context of gentilidade under one same category of offence bearing the same name. ${ }^{86}$ Either his choice of category was already part of the inquisitorial

84 Questions addressed to the General Council of the Holy Office by the inquisitors of Goa, answered in 1636. BNRJ, Inquisição de Goa, 25,1,004 no. 43, fols. 106r-106v.

85 Questions addressed to the General Council of the Holy Office by the inquisitors of Goa, answered in 1636. BNRJ, Inquisição de Goa, 25,1,004 no. 43, fol. 106r.

86 It is possible that the hard stance he took in 1619 against the "Gentilic features" adopted by Roberto Nobili, SJ, in the Madurai mission, which Figueira considered declarative ipsius gentilitatis may have favored the adoption of gentilidade as the general category of offence for actions that involved embracing the "false religion" of the Gentiles. On the discussions held in Goa on this matter, see Tavares, "Inquisição ao avesso", 20-21; Marcocci and Paiva, História da Inquisição Portuguesa, 214-215; Marcocci, "Rites and Inquisition", $155^{-161 .}$ 
lexicon practiced in Goa, or it came to generate consensus in subsequent years, since the term gentilidade was eventually adopted as a category of offence in the lists of autos-da-fé during the second half of the 17th century and the 18th century. 87

The General Council's decision to accuse the "Indios" when the rites they performed were "of this quality and nature", 88 equated, in practice and in spite of the style recently followed in the Goa Inquisition, the offence of gentilidade with that of heresy, which meant that the inquisitors should follow the manner of proceeding accordingly. Some decades later, in 1659, when the inquisitors Paulo Castelino de Freitas and Fr. Lucas da Cruz, OP, sent a new consultation to the General Council regarding a "cristão da terra detained on charges of gentilidade", the use of language did not vary. ${ }^{89}$ The basis for forming such charges were still "declarative (protestativas) ceremonies" and the confession of regarding the "pagode as God". The problem that the inquisitors were addressing was whether a case with these characteristics, in which the defendant claimed to have hope of being saved "in the faith of Christ", constituted formal or material heresy, with implications to the degree of punishment. The debate again focused on the will and level of pertinacity necessary to attest to the defendant's malice and rejection of Christian doctrine. Freitas thought it inconceivable that someone who confessed rites and declarative ceremonies and performed them to the pagodes, recognizing them as God, could simultaneously hope to be saved in Christ. ${ }^{90}$

87 In 1616, the inquisitors still referred to the actions of one Salcete-born man, João Martins, as idolatry, whereas Figueira labeled his offence as one of gentilidade in 1623. However, the oldest extant auto-da-fé list after the one of 16o9-1610 already refers to several individuals brought on charges of gentilidade. The category does not seem to have remained in effect for the entirety of the court's activity for, in 1766, the plural gentilidades was employed in the auto-da-fé list. Only a thorough examination of the extant correspondence could help determine the semantic variations of this category over time, which is outside the scope of this study. Letter from the inquisitors of Goa to Fernão Martins Mascarenhas, Inquisitor General of Portugal, December 23, 1616, Goa. Baião, A Inquisição de Goa, vol. 2, 547; List of individuals that took part in the auto-da-fé of the Goa Inquisition of April 3-4, 165o. Antr, Tribunal do Santo Ofício, Conselho Geral do Santo Ofício, maço 33, no. 1; List of individuals that took part in the auto-da-fé of the Goa Inquisition of September 21, 1766. Antr, Tribunal do Santo Ofício, Conselho Geral do Santo Ofício, maço 31, no. 13.

88 Questions addressed to the General Council of the Holy Office by the inquisitors of Goa, answered in 1636. BNRJ, Inquisição de Goa, 25,1,004 no. 43, fol. 106r.

89 Letter by Paulo Castelino de Freitas and Fr. Lucas da Cruz, OP, inquisitors of Goa, to Diogo Velho, secretary of the General Council of the Holy Office, February 6, 1659, Goa. BNRJ, Inquisição de Goa, 25,1,006 no. 34, fol. 48r.

90 Letter by Paulo Castelino de Freitas and Fr. Lucas da Cruz, OP, inquisitors of Goa, to Diogo Velho, secretary of the General Council of the Holy Office, February 6, 1659, Goa. BNRJ, Inquisição de Goa, 25,1,006 no.34, fol. 48v. 
The opinion of this inquisitor, subsequently validated by the General Council of the Holy Office, nevertheless illustrates a recurrent tension within the Goa Inquisition. As can be seen from subsequent consultations and appeals sent to Lisbon, the local devotional setting of Portuguese domains divided inquisitors over the value that should be attributed to the presumption that the practice of rituals and ceremonies identified as Gentilic implied adherence to the "sect of the Gentiles". For example, in 1726, the prosecutor filed an appeal against the court's sentence in the case of one Joana, protesting that the inquisitors did not want to examine the defendant as to the intention with which she had committed the offences she was accused of. In the prosecutor's opinion, her actions, even if strictly not heretical, could give rise to doubts, considering that she was a commoner and a daughter of Gentiles who professed the same sect, and that she lived in the Northern lands where "similar mistakes with withdrawal from faith are frequent, and almost customary". ${ }^{91}$ Furthermore, he stated that:

since the errors and rites of this gentilidade, and of those who follow them, consist of gifts to the pagodes with withdrawal [apartamento] from faith as is always seen in this court, and even if this fact is not judged as heretic, obviously one sees the great suspicion that results from it; and even if the act is not declarative [protestativo] of a sect, saltem, it is indicative. ${ }^{92}$

The inquisitors, it should be said, rejected the prosecutor's appeal, alleging that the defendant confessed to the offences of which she had been accused. They believed that the cristãos da terra performed "said ceremonies, and others of the same quality, without any malice, nor more foundation than for simplicity, and because their forefathers used to do so, from which, ad plurimum, can result a slight presumption of [the defendants] performing them with belief in idols, and gentile sect".93

$91 \quad$ Procedures against Joana "Curumbim" by the Inquisition of Goa, 1726. ANTT, Tribunal do Santo Ofício, Inquisição de Lisboa, no. 17048, fol. 19r.

92 Procedures against Joana "Curumbim" by the Inquisition of Goa, 1726. ANTT, Tribunal do Santo Ofício, Inquisição de Lisboa, no. 17048, fol. 20: "como os erros, e ritos desta gentilidade, e dos que o seguem são offertas aos pagodes com appartamento da fe como sempre se está uendo esta Verdade neste Tribunal, e quando este facto se não julgue por heretico euidentemente Se Vé a grande Suspeita, que delle resulta; e ainda que o acto não he protestatiuo de Seita saltem hè indicatiuo; e basta para poder ser accusada ad indagandam Veritatem".

93 Procedures against Joana "Curumbim" by the Inquisition of Goa, 1726. ANTT, Tribunal do Santo Ofício, Inquisição de Lisboa, no. 17048, fol. 22v: "[...] as ditas cerimonias, e outras da mesma qualidade, sem malicia algũa, nem mais fundamento, que por simplicidade, e 
The difference of opinions between the prosecutor and the inquisitors demonstrates the existence of distinct sensitivities within the Holy Office of Goa, something that had already occurred in the 1659 consultation. On that occasion, Fr. Lucas da Cruz argued that those who expected only material goods from the pagodes should not be accused of formal heresy, but only material. He added that among the errors of the cristãos da terra was the fact that they had many gods to take care of their houses, the rice fields, or the sea. ${ }^{94}$ By insinuating, with these examples, a space of material but not spiritual expectations, Cruz intended to remove the stigma of formal condemnation for gentilidade from several of the ritual behaviors displayed by local Christianity. The different understandings of what might indicate presumption of adherence to the "Gentile sect", and therefore wavering from faith, were also present in the dispute between the prosecutor and the inquisitors of Goa in 1726 - a dispute which was decided in favor of the former. ${ }^{95}$

porque seus antepacados assim o costumauão faser, do que ad plurimum pode resultar hũa leue presumpcão de as poderem faser com crença nos J[d]ollos, e Seita gentilica".

Letter from Paulo Castelino de Freitas and Fr. Lucas da Cruz, OP, inquisitors of Goa, to Diogo Velho, secretary of the General Council of the Holy Office, February 6, 1659, Goa. BNRJ, Inquisição de Goa, 25,1,006 no. 34, fols. 49r-49v.

95 It is worth noting that in the judicial practice of the Holy Office of Goa, the matter of gentilidade has been discussed as a form of heresy and not directly regarding what it could formally mean as apostasy. Resuming the juridical debate that preceded him, Francisco Suárez ( $\dagger_{1617}$ ) pointed out that Christians who turned (transiens) to Judaism or Paganism committed an act of apostasy because they fully rejected faith in Christ. In the inquisitorial praxis, however, the notion of infidelity in the assessment of guilt prevails, as can be seen from the prosecutor's opinion in Joana's case. In referring to the practice of Gentilic ceremonies, he stated that those who exercised them should be considered infidels "ac [p] er conseque $<\mathrm{n}>\mathrm{s}$ hæreticus" in accordance with the provisions of Boniface viII's Liber Sextus, which in 1298 collected the decretals subsequent to Pope Gregory IX in a single volume. There it was stipulated that the procedure against those who went back to observing the Jewish rites should be the same used against the heretics ("Contra christianos, qui ad ritum transierint vel redierint Iudæorum (...) tanquam contra hæreticos (...) procedendum"). Eimeric reflects the spirit of this legislation in the title De Apostatis, stating that those who apostatized "a fide etiam et ab Ecclesia totaliter deuiant. Et tales hæretici, immo infideles habendi sunt". Sextus liber, lib. 5, tit. De hæereticis, c. 13; Eimeric, Directorium Inquisitorum, part. 2, quæst. 49, art. 4, 364; Suárez, Opus de triplice virtute theologica. De fide, part. 2, disp. 16, sect. 5, art. 3, col. 591; Procedures against Joana "Curumbim" by the Inquisition of Goa, 1726. ANTT, Tribunal do Santo Ofício, Inquisição de Lisboa, no. 17048, fols. 19v-2or; Letter from the General Council of the Holy Office to the inquisitors of Goa, 13 April 1728, in Western Lisbon. Antr, Tribunal do Santo Ofício, Conselho Geral do Santo Ofício, liv. 102, fol. 139r. 


\section{The Offence of Gentilidade: A Specificity of Goa?}

Fifteen years into the creation of the Inquisition of Goa, the matter of how to treat the newly converted gained broader proportions. From 1576 onwards, different inquisitor generals strived to negotiate a papal exception for the newly converted, something that had very likely to do with the many occurrences involving the return to local practices in Goa. Although the Reportorio does not indicate many charges of gentilidade at this time, the matter was addressed in the 1576 letter written by Cardinal Henrique to the inquisitor in Goa, in which he ordered that the cases of relapses be suspended until further notice. ${ }^{96}$ This is indicative of the greater relevance that this type of crime was acquiring in the activity of this court. The papal grace that allowed absolution for repeated offenders on charges of heresy was only obtained in 1599, thus preventing the imposition of the capital sentence on the newly converted. ${ }^{97}$

At that time, accusations on grounds of gentilidade were on the rise in Goa, as shown in Chart 7.2, above. A comparison with Brazil should be made in this regard; the years when gentilidade proceedings began to increase in the Inquisition of Goa were also years in which Gentilic ceremonies were under scrutiny by another court, namely that of Lisbon, through the visit (visitação) led by Heitor Furtado de Mendonça to the captaincies of Bahia (1591-1593) and Pernambuco (1593-1595) in Brazil. In particular, it was during his long stay in Salvador that H. F. de Mendonça came into contact with the phenomenon mentioned in documents as Santidade, a movement of indigenous origin deeply penetrated with contents from the Catholic religious and devotional world. Between c. 1580 and 1586-the year in which it was suppressed-the movement brought together natives of the sertão (hinterland), Christianized Amerindians, mestizos, Africans, and even Europeans. ${ }^{98}$ According to the testimonies collected by H. F. de Mendonça, the unlawful behaviors practiced in this context suggest a parallelism with the Asian setting: genuflections and idol worship, reverence in the manner of the "gentios", Gentile ceremonies and adorations, etc.

96 Letter from Cardinal Henrique, Inquisitor General of Portugal, to Bartolomeu da Fonseca, inquisitor of Goa, February 15, 1576. Baião, A Inquisição de Goa, vol. 1, 298; Marcocci, "A fé de um império", 87 , fn. 77 .

97 On this brief, see Marcocci, "A fé de um império", 86-88; Marcocci and Paiva, História da Inquisição Portuguesa, 113-115.

98 Calasans, Fernão Cabral de Ataíde e a Santidade de Jaguaripe; Vainfas, A heresia dos índios, 141; Metcalf, "Millenarian Slaves?". 
Recently, Jamille Cardoso argued that H. F. de Mendonça qualified the offences of those involved in the Santidade movement as heresy. ${ }^{99}$ I found no documentary evidence to sustain this hypothesis, since none of the cases relating to the Santidade expressly refers to a category of crime within which to frame the proceedings. In fact, neither the rulings (acórdãos) of the vote of the board of the visit, nor the trial sentences, present indicators that describe the movement as heretical or a heresy. ${ }^{100}$ To the contrary, the Santidade is consensually designated as abusão and erronia, often together, terms sometimes qualified with the adjective Gentilic. This is, therefore, a lexical frame closer to superstition than to heresy. If, in rhetoric, abusão is the improper or abusive use of one word to designate another, in this context it should be understood as "superstitions of those who abuse or misuse various things, [that] by their nature [are] disproportionate to the intended objective", and also "common error". ${ }^{101}$ According to Bluteau, on the other hand, erronia means "error", "opinion", "maxim", "wrongful imagination", which is a "palavra do vulgo", i.e., a word used by the common folk. ${ }^{102}$

These same meanings, moreover, are found in the Jesuit documents that refer to the movement prior to the inquisitorial visit and are therefore independent of it. Both the Informação do Brasile de suas capitanias of 1584 and the Annual Letter from the Brazilian mission of 1585 , published in Rome two years later, coincide with a framework in the field of superstition. The Informação do Brasil, written before the suppression of the Santidade, does not refer to a specific movement, but to the frequent mobilizations of Amerindians by "sorcerers", characterized as charlatans creating an "invention (invenção) from which he thinks he will profit". ${ }^{103}$ The terms most commonly used in this document are "inventions" and "lies". Its author suggests that the Amerindians were

99 Cardoso, Ecos de Liberdade, 138.

100 The only circumstances in which the term heresy was mentioned in the judicial sentences of those who adhered to the Santidade movement was when the defendants were also prosecuted for not respecting the precepts of not eating meat during Lent, something that, in the inquisitorial processology, was considered as an "heretical fault". Pantaleão Ribeiro's testimony contains the statement that followers of Santidade spoke in the Holy Trinity with "heretical errors". However, this statement is isolated and was not included in the final sentence despite the very close proximity between the narratives of the testimonies and those of the sentences. Procedures against Pantaleão Ribeiro by the Inquisition of Lisbon, 1591. ANTT, Tribunal do Santo Ofício, Inquisição de Lisboa, no. 11036, fol. 15 . VPL, 1712, s. v. "abusão": "superstiçoens dos que abusão, ou usão mal de varias cousas, por sua natureza desproporcionadas para o fim, que intentão"; Moraes (1789) s. v. "abusão": "Erro vulgar".

102 VPL, 1713, s. v. "erronia": "Erro. Opinião, maxima, imaginação errada".

103 Anchieta, Cartas, Informações, Fragmentos Historicos e Sermões, 331. 
even aware of the inherent falsehood of these sorcerers' actions, ${ }^{104}$ and he concludes by saying that they had many "other agouros (omens) and abusões", the latter being the same word that was extensively repeated in the inquisitorial proceedings. ${ }^{105}$ In turn, the Annual Letter of 1585 refers precisely to the phenomenon that became known as Santidade and assumes its hybrid character of indigenous origin impregnated with Christian contents. In this document, Santidade is simultaneously a "superstition" (nouum inter Indios superstitionis genus est ortum) and a "ridiculous" "madness" (Ad hanc vel superstitionem uel amentiam adiungitur illa non minus ridicula). ${ }^{106}$

The consensus on how to define Santidade in the trial records of the inquisitorial visit should thus express not only the memory of the events among the population, but also a memory formatted into a terminology of its own, a process in which the Society of Jesus itself must have participated. As Ronaldo Vainfas recalled, the indoctrination of the Indians who adhered to Santidade was largely a responsibility of the Society of Jesus. ${ }^{107}$ A possible intention to attenuate a close connotation between the movement and heresy in the description of events should not be overlooked.108 These elements suggest that, in transposing the characterization of the movement into his own legal, inquisitorial framework, H. F. de Mendonça did not steer away from the crystallized portrayal of Santidade in Bahian society. In fact, he continually alluded to the movement as abusão, erronia, and even idolatry, in absolute conformity with the statements of the confessants, denouncers, and defendants, not to mention Governor Teles Barreto himself. ${ }^{109}$ On the contrary, the use of the term sect, which tends to be more closely associated with the notion of heresy, is almost absent from the testimonies and was on no occasion included by the board of the visit, either in their decisions or in the judicial sentences. ${ }^{110}$

104 Anchieta, Cartas, Informações, Fragmentos Historicos e Sermões, 331.

105 Anchieta, Cartas, Informações, Fragmentos Historicos e Sermões, 331-332.

106 Annuce Litterce Societatis Iesv Anni 1585, 133-134.

107 Vainfas, A heresia dos índios, 150-151.

108 Conversely, Vainfas sees in some aspects of the 1585 Annual Letter elements that point to framing the Santidade movement as heresy, such as having books of their own. See Vainfas, $A$ heresia dos índios, 208-209.

109 Certificate by Manuel Teles Barreto, governor of Brazil, August 8, 1586, in Procedures against Fernão Cabral de Ataíde by the Inquisition of Lisbon, 1591-1593. ANTT, Tribunal do Santo Ofício, Inquisição de Lisboa, no. 17065, fol. 17ır.

110 A characteristic of the trial records from the inquisitorial visit to Brazil is the overlapping of narratives of the deponents (their testimonies) and those attributed to the visitor or to the inquisitorial board (interrogations, decisions, and judicial sentences). The record of the testimonies was copied almost ipsis litteris into the text of the judicial sentences, making it very hard to ascertain and outline the autonomy of each narrative recorded 
For the purposes of judgment, perhaps the adoption of a term of its own was not necessary, due to the presumption of heresy identified in different forms of superstition, of which idolatry was one. ${ }^{111}$ However, the language used to characterize the movement in the inquisitorial documentation steers away from a direct identification as heresy, as can be appreciated from the way ritual practices are referred to. The testimonies refer to what is practiced in Santidade as despropósitos (nonsense), invenção, imperfeições (imperfections), and the counterfeiting of Church customs - terms that largely point to errors in the exterior forms of cult, i.e., to ritual practices and not to doctrine. ${ }^{112}$ As a result, they place the movement in opposition to an organized belief system, because no law or doctrine was attributed to it. For example, when asked about "what substance and what law was that of the abusão so-called Santidade", Pantaleão Ribeiro replied that:

a Brazilian Christian named Antonio, who was raised in the villages of conversion, fled into the sertão and there invented this erronia called Santidade, which in itself has no order, no certainty, no rule, but to howl and honk, having no god in particular, [...] and speak in the most holy Trinity, with no purpose, and heretical errors, so that they live like this without any significance. ${ }^{113}$

Although, as Ribeiro's testimony proves, there were those among the residents of Bahia who used the image of heresy to characterize the movement, it was not the predominant representation and other elements prevailed. ${ }^{114}$ In Santidade, its lack of intellectual depth, its Gentile origin, and its distorted understanding

during the visit. In light of this, it is interesting to note the absence of terms such as heresy and sect from the judicial sentences. The term sect was used by Fernão Cabral de Ataíde to address the Santidade movement, and H. F. de Mendonça even inquired why he invited that "sect of idolatry" into his property, but that is as far as he went, and he did not use the term again. Procedures against Fernão Cabral de Ataíde by the Inquisition of Lisbon, 1591-1593. ANTT, Tribunal do Santo Ofício, Inquisição de Lisboa, no. 17065, fols. 168v-169v.

111 Paiva, Bruxaria e Superstição, 56-59; Lara Cisneros, ¿Ignorancia invencible?, 91-112.

112 Jean-Baptiste Thiers, collecting and systematizing the production that preceded him, wrote in 1679 that superstition was the domain of cults and undue practices, whether by defect, excess, content or form, or latria: "Si bien que l'on est veritablement Superstitieux lorsque l'on ne donne pas à Dieu ce qui luy appartient; lorsque l'on donne à la creature plus qui'il ne faut; lorsque l'on donne au Createur autre chose qu'il ne demande, \& d'une autre maniere qu'il ne demande; lorsque l'on rend à tout autre qu'à Dieu un culte de latrie". In listing the different forms of superstition, the author makes use of the terms abus, and excés. Thiers, Traité des Superstitions selon l'Écriture Sainte, 4-5.

113 Procedures against Pantaleão Ribeiro by the Inquisition of Lisbon, 1591. ANTT, Tribunal do Santo Ofício, Inquisição de Lisboa, no. 11036 , fols. 14v-15r.

114 The wide range of perceptions about the movement, from superstition to heresy, had already been noted by Ronaldo Vainfas. See Vainfas, A heresia dos índios, 172. 
of the contents of the Christian message all may have contributed to blurring the characteristics more strongly associated with the heretic: the understanding (contrary doctrinal formulation) and the will (pertinacity in remaining in error). ${ }^{115}$ The prevalence of a vocabulary that highlighted the absurd and imperfect nature of the practices of Santidade attests, as such, to a greater proximity to the semantic field of superstition than to that of formal heresy. ${ }^{116}$

In Brazil, therefore, there prevailed the notion that the Gentilic humus that nurtured the Santidade had generated an idolatrous practice which, perhaps due to the Christian elements that constituted it, did not involve a doctrine or law that could be considered indigenous to Brazil's gentilismo, contrary to what was happening in Asia.

The confession of Pêro Bastardo-a Portuguese man who lived in the hinterland of Raribe (Sergipe) — to living according to the "Gentilic way" can help us understand the dissociation between the Gentilic practices of Brazil and a charge of gentilidade. Asked by H. F. de Mendonça what the belief or law of the gentilidade of the Raribe Indians was and whether they worshipped idols or pagodes, he answered that:

the Gentiles among whom he lived have no idols, nor pagodes, nor law, nor belief, nor faith; and that they believe only in what their sorcerers, their preachers, say to them, which is a thousand things without purpose, for example, when there are thunderstorms and storms, they say that what it means is that god commands them to sow and plant. ${ }^{117}$

Bastardo's opinion undoubtedly replicated the understanding shared by many about the Amerindians of Brazil. As early as 1549, when the Jesuit mission began, Father Manuel da Nóbrega, in a much-quoted passage, said that they were "people who have no knowledge of God, or idols". ${ }^{118}$ This same idea is reproduced in the Informação do Brasil, which states that they "adore no creature as God — only the thunder do they believe is God — but they do not grant

\footnotetext{
115 See above, fn. $5^{2}$.

116 Célia Tavares classifies the movement as "a very interesting type of gentilismo". If we take gentilismo to mean the action of withdrawing from faith and adhering to the "sect of the Gentiles", then the equivalence with the judicial category of gentilidade as used in Goa seems ill adjusted in light of the Christian contents of Santidade, pointed out in several of the testimonies. Tavares, "A Inquisição e a Companhia de Jesus diante do 'Gentilismo', 6.

117 Procedures against Pêro Bastardo by the Inquisition of Lisbon, 1594. ANTT, Tribunal do Santo Ofício, Inquisição de Lisboa, no. 1318o, fols. $3^{\mathrm{r}}-3^{\mathrm{v}}$.

118 Letter from Father Manuel da Nóbrega, SJ, to Father Simão Rodrigues, SJ, [April 10?] 1549, Bahia. Leite, Cartas do Brasil e mais escritos do P. Manuel da Nóbrega, 21.
} 
it any honor, nor do they commonly have idols, nor sortes (fortune telling), nor communication with the Devil, although they are afraid of him".119

It is possible that the absence of religious attitudes translatable into a system of beliefs - consisting of "law", "doctrine", and "sect" — disqualified, in the inquisitorial judgment, Gentilic practices as deserving of a specific legal framework, similar to what occurred at that time in Goa. The decision about Bastardo's sentence, which had nothing to do with the Santidade movement but concerned only the assumption of Gentilic customs in the hinterland of Raribe, stated that the defendant "confessed to his Gentilic offences", asserting that "he was never a Gentile in his mind nor did he leave the faith". However, it is not clear from the procedures whether the suspicion which rested on him resulted in an apostasy offence or whether "having their gentilidade [of Brazil's Indians]"120 gained, in the visitor's mind, the same kind of significance as a particular type of offence as was happening in Goa. The matter did not escape the attentive eye of Vainfas, who stressed on numerous occasions that H. F. de Mendonça was not prepared to appreciate the Gentilic elements mentioned in the confessions he had received, and that he found it difficult to classify them into pre-existing categories. ${ }^{121}$ However, the trials conducted during the visit were covered by the exceptional procedural circumstances established by a period of grace (tempo da graça) of one month, during which those who spontaneously appeared before the visitor to confess their faults were promised lenient treatment and exemption from the confiscation of assets. As such, trials such as those of Bastardo did not lead to thorough interrogations regarding the "Gentilic faults" that the visitor attributed to him because he confessed during the period of grace. The same applies to the cases of Lázaro da Cunha, who was questioned about whether he believed he could save himself "in that gentilidade" (of the Gentiles of Raribe), or that of Iria Álvares, who, having adhered to Santidade but not been put in a position to worship idols, was prosecuted for believing in the abusão and erronia and for having participated in other ceremonies, without it being possible to assess whether this particularity deserved specific considerations on the part of the visitor. ${ }^{122}$

119 Anchieta, Cartas, Informações, Fragmentos Historicos e Sermões, 331.

120 Procedures against Pêro Bastardo by the Inquisition of Lisbon, 1594. ANTT, Tribunal do Santo Ofício, Inquisição de Lisboa, no. 13180, fols. 11v-12r.

121 Vainfas, A heresia dos índios, 1995, reprint 2010, 168, 171, 181. As mentioned, this was not something unique to H. F. de Mendonça. The General Council of the Holy Office at Lisbon was also puzzled by the information conveyed by the inquisitors of Goa, requesting clarifications on what the realities they were describing actually meant. See, above, p. 224. 1593 and 1595. ANTt, Tribunal do Santo Ofício, Inquisição de Lisboa, no. 11068 and 1335, respectively. 
We cannot determine that, at the end of the 16th century, gentilidade already formed a category of offence that had been sufficiently discussed and publicized as such to the other inquisitorial courts, such as Lisbon. What is known, as demonstrated above, is that the Inquisition exhibited, since the end of the 1570s, special attention to the newly converted, even dispatching two commissions to the bishops of Brazil and China in 1579 to proceed locally against the newly converted, avoiding the inconvenience of a costly displacement of defendants to Lisbon and Goa. ${ }^{123}$ However, it is difficult to determine whether the lack of prosecution on grounds of gentilidade in Brazil's 16th-century procedures derived from want of normalization of the term or from the fact that, in this period, the Holy Office did not recognize an autonomous law or doctrine that could be identified as a sect in Brazil's gentilidade. While inquisitorial perceptions of gentilismo and gentilidade in the Atlantic World have yet to receive broad treatment by scholars, preliminary analysis of later trial records relating to Brazil or Angola that involved Gentilic practices did not evolve into formal accusations of gentilidade, as was the case in Asia, but rather into accusations of idolatry or demonic pact. ${ }^{124}$

\section{Final Remarks}

In Asia, the recognition of a specific religious offence was likely the result of a court functioning in a completely non-European setting, on an island where direct contact with gentilidade was to be had by the simple act of crossing a river. In the 1590s, the Holy Office itself must have begun to find it difficult to assert the relevance of its activity via the European population sector, particularly

\footnotetext{
123 Lourenço, "Bispo da China e Inquisidor Apostólico".

124 Indeed, an accusation on gentilidade seems to be absent from the choices of categorization as is the case in the procedures against João Pereira da Cunha, who was a captain in the fort of Ambaca (Angola) (Procedures against João Pereira da Cunha by the Inquisition of Lisbon, 1749-1766. ANTT, Tribunal do Santo Ofício, Inquisição de Lisboa, no. 9691). As for Brazil, later cases studied by James Wadsworth such as the Jurema Cult in Paraíba and the batuque controversy in Pernambuco-both in the 18th century - seem to make use of a lexicon associated to the Indian's religious world such as "invention" and "diabolical witchcraft", as well as idolatry. In both cases we may find mentions of Indians and slaves from Angola adoring "smoke [...] instead of God" or "false divinities". However, the types of offence associated with such beliefs were either divinations or "a sort of idolatry". Letter from José Ferreira Passo [to the Lisbon Inquisition], February 12, 1759, Paraíba. ANTT, Tribunal do Santo Ofício, Inquisição de Lisboa, maço 40, doc. 79; Requirement by Alexandre Jansen Moller, prossecutor of the Lisbon Inquisition, to the inquisitors [undated, c. 1779, Lisbon]. ANTt, Tribunal do Santo Ofício, Inquisição de Lisboa, no. 4740, fol. 3; Wadsworth, "Jurema and Batuque", 144. See also Resende, "Da ignorância e rusticidade", 97 et seq.; Marcocci and Paiva, História da Inquisição Portuguesa, 323-324.
} 
through the offences of Judaism or Lutheranism, which had dropped to insignificant levels since the early 158 os. If we focus on the types of crime that imply adherence to another belief system, the comparison of the evolution of the cases followed by the Goa Inquisition in this period shows an increase in the trials of "Moor" and gentilidade. The renewal of the court's social function, of its legitimation in the Estado da Índia, was achieved by reorienting its repressive activity towards other types of crime. This shift meant, in the court's relationship with its immediate surroundings, the creation or the reinforcement of a new type of crime classification, that of gentilidade, but above all, of a new profile of delinquent: the cristão da terra.

It was these types of defendants that, from the 158 os until the definitive abolition of the Goa Inquisition, constituted the majority of the culprits prosecuted by the court. The cases of gentilidade became a recurrent feature in the lists of autos-da-fé. Convictions on gentilidade multiplied amid what can be perceived as an underlying uneasiness inside the Inquisition of Goa between its ministers. The ever-resurging question of the inherent value of the ceremonies and practices of the local populations divided inquisitors on where to draw the line of apostasy and heresy with regards to the diversity of behaviors of local Christians. The lack of preparation that Vainfas noticed in H. F. de Mendonça may have been due to the overwhelming challenges posed by the colonial world and faced by the visitor's notions or classifications of religious dissent. If that were the case, his attitude would not have differed from that of his colleagues in Goa, who faced similar challenges about where in the legal framework at their disposal they should place each misconduct. For them, the line that separated gentilidade from other crimes zigzagged between sumbaias, pagodes, ceremonies, sacrifices, and other circumstances of local life in the 'Old Conquests' or the 'Northern Province,' depending on the reaches of each defendant's intent (tenção). This line, however, was not fixed and likely depended on the personalities and education of each inquisitor and prosecutor and on the circumstances of the court's activities.

The edict of 1736 , by discriminating against a whole panoply of practices previously considered as "political" or "non-declarative" of adherence to the "sect of the Gentiles", likely reinforced a tendency amongst the ministers of the Inquisition to perceive in each case that involved gentilidades a potential case of apostasy - an offence that was equivalent to that of heresy for the purposes of judicial procedure. In itself, the choice to claim broader jurisdiction over local customs is indicative of the accumulated pressure felt by different generations of inquisitors in dealing with their entourage and the frustration over not being able to overcome what they perceived as the shortcomings of mission and Inquisition.

Although a network of commissioners of the Holy Office was established in Brazil, the territory never had a functioning court. As such, the issue of 
the faith of the converted populations remained ever distant from the Inquisition of Lisbon's priorities, unlike in Goa. Here, the Inquisition operated in an entirely colonial territory surrounded by a majority of newly converted Catholics and their descendants. The interaction with the universe of gentilidade was an insurmountable reality, which had furthermore been intensified by decades of intense extirpation of idolatry campaigns and hostile policies towards local customs by Portuguese authorities. The emergence of a crime called, by the inquisitors, by the same name as the environment in which local beliefs originated, thus reflects the great difference between the Holy Office of Goa and the other Portuguese inquisitorial courts. Unlike Brazil and Angola, which were too far away from Lisbon and its inquisitors' eyes, the reality of individuals who were continuously crossing the river to the terra firme and apostatizing or performing the ceremonies and rituals of gentilidade was a matter directly witnessed and widely discussed by the ecclesiastical authorities residing in Goa. While the Inquisition in Lisbon remained, in essence, a European inquisitorial tribunal, Goa became a truly Asian one, particularly after trials on Judaism there dwindled. The emergence of a category whose name was taken from the term that defined the socio-religious otherness of the Gentiles testifies to the extent that the colonial context imposed itself on the court's activities. Gentilidade, re-signified by the Inquisition of Goa as a category of religious offence for apostatizing to the "sect of the Gentiles", became the legal expression of this reality.

\section{Acknowledgements}

This study was conducted as part of the project "Religiosidad nativa, idolatría e instituciones eclesiásticas en los mundos ibéricos, época moderna”. Proyecto PAPIIT IG40o619. Universidad Autónoma de México (UNAM). I wish to thank Gerardo Lara Cisneros for his attentive observations, as well as Manuel Bastias Saavedra and the two anonymous reviewers. I am also indebted to Ana Santos Pereira, Andrea Cicerchia, Dale Menezes, Jessica J. Fowler, João Eleutério, Paolo Aranha, Roger Lee de Jesus, and Susana Bastos Mateus.

\section{Bibliography}

\section{Manuscripts}

Arquivo Nacional Torre do Tombo (ANTT), Tribunal do Santo Ofício, Conselho Geral do Santo Oficio, Reply of the General Council of the Holy Office to the memorandum 
by André Fernandes, acting inquisitor of Goa, undated (c. March 1584), liv. 311, fols. 91r-92v.

Arquivo Nacional Torre do Tombo (ANTT), Tribunal do Santo Ofício, Conselho Geral do Santo Ofício, Ruling of the General Council of the Holy Office regarding the list of individuals sentenced by the Goa Inquisition in 1594, [March 16] 1596, liv. 10o, fols. $78 \mathrm{r}-78 \mathrm{v}$.

Arquivo Nacional Torre do Tombo (ANTT), Tribunal do Santo Ofício, Conselho Geral do Santo Oficio, List of individuals tried by the Inquisition of Goa in the year 1609 and 1610, undated, liv. 369, fols. 2or-39r.

Arquivo Nacional Torre do Tombo (ANTT), Tribunal do Santo Ofício, Conselho Geral do Santo Ofício, List of individuals that took part in the "auto-da-fé" of the Goa Inquisition of April 3-4, 1650, maço 33, no. 1.

Arquivo Nacional Torre do Tombo (ANTT), Tribunal do Santo Ofício, Conselho Geral do Santo Ofício, Letter from the General Council of the Holy Office to the inquisitors of Goa, April 13, 1728, Western Lisbon, liv. 102, fols. 136v-143v.

Arquivo Nacional Torre do Tombo (ANTT), Tribunal do Santo Ofício, Conselho Geral do Santo Ofício, List of individuals that took part in the "auto-da-fé" of the Goa Inquisition of September 21, 1766, maço 31, no. 13 .

Arquivo Nacional Torre do Tombo (ANTT), Tribunal do Santo Ofício, Inquisição de Coimbra, Procedures against Luísa da Fonseca by the Inquisition of Coimbra, 1728, no. 7339 .

Arquivo Nacional Torre do Tombo (ANTT), Tribunal do Santo Ofício, Inquisição de Lisboa, Procedures against Pantaleão Ribeiro by the Inquisition of Lisbon, 1591, no. 11036.

Arquivo Nacional Torre do Tombo (ANTT), Tribunal do Santo Ofício, Inquisição de Lisboa, Procedures against Fernão Cabral de Ataíde by the Inquisition of Lisbon, 1591-1593, no. 17065 .

Arquivo Nacional Torre do Tombo (ANTT), Tribunal do Santo Ofício, Inquisição de Lisboa, Procedures against Lázaro da Cunha by the Inquisition of Lisbon, 1592-1593, no. 11068.

Arquivo Nacional Torre do Tombo (ANTT), Tribunal do Santo Ofício, Inquisição de Lisboa, Procedures against Lopo Álvares by the Inquisition of Goa, 1594, no. 12738.

Arquivo Nacional Torre do Tombo (ANTT), Tribunal do Santo Ofício, Inquisição de Lisboa, Procedures against Pêro Bastardo by the Inquisition of Lisbon, 1594, no. 13180. Arquivo Nacional/Torre do Tombo (ANTT), Tribunal do Santo Ofício, Inquisição de Lisboa, Procedures against Iria Álvares by the Inquisition of Lisbon, 1595, no. 1335.

Arquivo Nacional Torre do Tombo (ANTT), Tribunal do Santo Ofício, Inquisição de Lisboa, Procedures against Francisco Rangel by the Inquisition of Goa, 1603-1605, no. 8916 . 
Arquivo Nacional Torre do Tombo (ANTT), Tribunal do Santo Ofício, Inquisição de Lisboa, Procedures against Joana "Curumbim" by the Inquisition of Goa, 1726, no. 17048. Arquivo Nacional Torre do Tombo (ANTT), Tribunal do Santo Ofício, Inquisição de Lisboa, Procedures against João Pereira da Cunha by the Inquisition of Lisbon, 17491766, no. 9691 .

Arquivo Nacional Torre do Tombo (ANTT), Tribunal do Santo Ofício, Inquisição de Lisboa, maço 40, doc. 79, Letter from José Ferreira Passo [to the Lisbon Inquisition], February 12, 1759, Paraíba.

Arquivo Nacional Torre do Tombo (ANTT), Tribunal do Santo Ofício, Inquisição de Lisboa, Requirement by Alexandre Jansen Moller, prossecutor of the Lisbon Inquisition, to the inquisitors [undated, c. 1779, Lisbon], no. 4740.

\section{Printed Sources}

Aquinas, Thomas, Summa Theologice. Online: https://aquinas.cc/la/en/ ST.I (January 27, 2021).

Annuce Litterce Societatis Iesv Anni MDLXXXV. Ad Patres, et Fratres eiusdem Societatis, Rome 1587: Collegio eiusdem Societatis.

Archivo Portuguez Oriental, fasc. 4, Nova Goa 1862, Third Ecclesiastical Council of Goa, 1585, 109-184.

Azpilcueta, Martín de, Manval de Confessores y Penitentes, que clara \& brevemente contiene, la vniuersal y particular decision de qvasi todas las dudas, que en las confessiones suelen ocurrir de los pecados, absoluciones, restituciones, censuras, \& irregularidades, Salamanca 1556: En casa de Andrea de Portonarijs.

Bluteau, Raphael, Vocabulario portuguez e latino, aulico, anatomico, architectonico, bellico, botanico, brasilico, comico, critico, chimico, dogmatico, dialectico, dendrologico, ecclesiastico, etymologico, economico, florifero, forense, fructifero [...], Coimbra $1712-1728$.

Boniface VIII, Sextus liber. Sexti libri argumentum multis signatum sillabis: Quis capita quater centum, quadraginta octo dabis, Paris 1510: Jean Chappuis.

Covarrubias Orozco, Sebastián de, Tesoro de la lengua castellana, o española, Madrid 1611: Luis Sanchez, impressor del Rey.

Eimeric, Nicolau and Francisco Peña, Directorium Inquisitorium [...], Venice 16o7: apud Marcum Antonium Zalterium.

Leite, Serafim (ed.), Cartas do Brasil e mais escritos do P. Manuel da Nóbrega, Coimbra 1955.

Real Academia Española (RAE), Diccionario de la Lengua Castellana: en que se explica el verdadero sentido de las voces [...], Madrid 1726-1739.

Rivara, Joaquim Heliodoro da Cunha, Ensaio Historico da Lingua Concani, Nova Goa 1858: Impr. Nacional. 
Silva, Antonio de Moraes, Diccionario da lingua portugueza composto pelo padre D. Raphael Bluteau, reformado, e accrescentado por [...], Lisbon 1789: Na Officina de Simão Thaddeo Ferreira.

Solórzano Pereira, Juan de, Politica Indiana, Madrid 1647: En la Officina de Diego Díaz de la Carrera.

Sousa, Francisco de, Oriente Conquistado a Jesu Christo pelos Padres da Companhia de Jesus da Provincia de Goa, vol. 2, Lisbon 1710: Na Officina de Valentim da Costa Deslandes.

Stammler, Johannes, Dialogus de diversarum gencium sectis et mundi religionibus, Augsburg 1508: Per Erhardum Oglin \& Ieorgi Nadler.

Suárez, Francisco, Opus de triplice virtute theologica. De fide, Spe, et Charitate, Paris 1621: Typis Edmundi Martini.

Thiers, Jean-Baptiste, Traité des Superstitions selon l'Écriture Sainte, les Décrets des Conciles et les Sentiments des Saintes Péres et des Theologiens, Paris 1679: Antoine Dezallier.

\section{Literature}

Amiel, Charles, "L'Inquisition de Goa”, in Borromeo, Agostino (ed.), L'Inquisizione. Atti del Simposio internazionale, 29-31 ottobre 1998, Vatican City 2003, 229-250.

Amiel, Charles, “Goa”, in Prosperi, Adriano, Vincenzo Lavenia and John Tedeschi (eds.), Dizionario Storico dell'Inquisizione, vol. 2, Pisa 2010, 716-718.

Anchieta, José de, SJ, Cartas, Informações, Fragmentos Historicos e Sermões, Rio de Janeiro 1933.

Aranha, Paolo, "Early Modern Asian Catholicism and European Colonialism: Dominance, Hegemony and Native Agency in the Portuguese Estado da Índia", in Koschorke, Klaus, Adrian Hermann (eds.), Polycentric Structures in the History of World Christianity, Wiesbaden 2014, 285-306.

Aranha, Paolo, Il Cristianesimo Latino in India nel XVI Secolo, Milan 2006.

Baião, António, A Inquisição de Goa. Correspondência dos Inquisidores de Goa (15691630), vol. 2, Coimbra 193 o.

Baião, António, A Inquisição de Goa. Tentativa de história da sua origem, estabelecimento, evolução e extinção (Introdução à correspondência dos Inquisidores da Índia. 1560-1630), vol. 1, Lisbon 1945.

Barbu, Daniel, “Idolatry' and Religious Diversity: Thinking about the Other in Early Modern Europe", in Asdiwal. Revue Genevoise d'Anthropolgie et d'Histoire des Religions 9 (2014): 39-50.

Bernand, Carmen and Serge Gruzinski, De la idolatría. Una arqueología de las ciencias religiosas, Mexico 1988 (repr. Mexico 2018).

Bethencourt, Francisco, História das Inquisições. Portugal, Espanha e Itália, [s.l.] 1994. 
Boucharb, Ahmed, Les crypto-musulmans d'origine marocaine et la société portugaise au XVIe siècle (PhD Thesis), 3 vols., Montpellier 1987.

Boulhol, Pascal, “Secta: de la ligne de conduite au groupe hétérodoxe, Évolution sémantique jusqu'au début du Moyen Âge”, Revue de l'histoire des religions 219:1 (2002): $5^{-33}$.

Burkardt, Albrecht, "Superstizione", in Prosperi, Adriano et al. (eds.), Dizionario Storico dell'Inquisizione, vol. 3, Pisa 2010, 1549-1551.

Calasans, José, Fernão Cabral de Ataíde e a Santidade de Jaguaripe, Madrid $195^{2}$ (repr. Salvador 2011).

Cardim, Pedro, "Os povos indígenas e as instâncias de justiça na América portuguesa e espanhola", in Domingues, Angela et al. (eds.), Os Indígenas e as Justiças no Mundo Ibero-Americano (Sécs. XVI-XIX), Lisbon 2019, 29-84.

Cardoso, Jamille Oliveira Santos Bastos, Ecos de Liberdade: a Santidade de Jaguaripe entre os alcances e limites da colonização cristã (1580-1595) (MA thesis), Salvador 2015 .

Castañeda Delgado, Paulino, "La condición miserable del indio y sus privilegios", in Anuario de Estudios Americanos 28 (1971): 245-335.

Congar, Yves, “Gentilis' et 'Iudaeus' au moyen âge”, in Recherches de théologie ancienne et médiévale 36 (1969): 222-225.

Cunha, Ana Cannas da, A Inquisição no Estado da Índia. Origens (1539-1560), Lisbon 1995 .

Dalgado, Sebastião Rodolfo, Glossário Luso-Asiático, vol. 1, Coimbra 1919.

Dalgado, Sebastião Rodolfo, Glossário Luso-Asiático, vol. 2, Coimbra 1921.

Eberenz, Rolf and Mariela de la Torre, Conversaciones estrechamente vigiladas: Interacción coloquial y español oral en las actas inquisitoriales de los siglos XV a XVII, Zaragoza 2003.

Evans, G. R., Alain of Lille. The Frontiers of Theology in the Later Twelfth Century, Cambridge 1983 .

Faria, Patricia Souza de, "De réus a colaboradores: Nativos convertidos ao catolicismo diante do tribunal da Inquisição de Goa”, in Revista Brasileira de História das Religiões 3:8 (2010), 165-182.

Faria, Patricia Souza de, "Os concílios provinciais de Goa: reflexões sobre o impacto da 'Reforma Tridentina' no centro do império asiático português (1567-1606)”, in Topoi, 14:27 (2013): 218-238.

Feitler, Bruno, "A Inquisição de Goa e os nativos: achegas às originalidades da ação inquisitorial no oriente", in Furtado, Júnia Ferreira et al. (eds.), Justiça, governo e bem comum na administração dos impérios ibéricos de Antigo Regime (séculos $X V$ XVIII), Curitiba 2017, 95-116. 
Feitler, Bruno, "João Delgado Figueira e o Reportorio da Inquisição de Goa: Uma base de dados. Problemas metodológicos", in Anais de História de Além-Mar 13 (2012): $531-537$.

Feitler, Bruno, "O Secreto do tribunal indiano da Inquisição portuguesa: entre Goa, Lisboa e Rio de Janeiro", in Revista de fontes 5:9 (2018): 36-5o.

Feitler, Bruno, "The Portuguese Inquisition and Colonial Expansion. The 'Honor' of Being Tried by the Holy Office", in Del Valle, Ivonne et al. (eds.), Iberian Empires and Roots of Globalization, Nashville 2020, 105-130.

George-Tvrtković, Rita, "Deficient Sacraments or Unifying Rites? Alan of Lille, Nicholas of Cusa, and Riccoldo da Montecroce on Muslim and Jewish Praxis", in Levy, Ian Christopher, Rita George-Tvrtković and Donald F. Duclow (ed.), Nicholas of Cusa and Islam. Polemic and Dialogue in the Late Middle Ages, Boston 2014, 105-122.

Henn, Alexander, "Shrines of Goa: Iconographic Formation and Popular Appeal", in South Asia Multidisciplinary Academic Journal, no. 18 (2018): 1-17.

Humfress, Caroline, "Roman law, forensic argument and the formation of Christian Orthodoxy (III-VI centuries)”, in Elm, Susanna, Éric Rebillard and Antonella Romano (eds.), Orthodoxie, Christianisme, Histoire, Rome 2001, 125-147.

Humfress, Caroline, Orthodoxy and the Courts in Late Antiquity, Oxford 2007.

Lara Cisneros, Gerardo, ¿Ignorancia invencible? Superstición e idolatría ante el provisorato de Indios y Chinos del Arzobispado de México em el siglo XVIII, Mexico 2014.

Le Boulluec, Alain, La notion d'héresie dans la littérature grecque. II ${ }^{\mathrm{e}}-I I \mathrm{I}^{\mathrm{e}}$ siècles, 2 vols. Paris 1985 .

Lopes, Maria de Jesus dos Mártires, "A Inquisição de Goa na primeira metade de Setecentos", Mare Liberum, no. 15 (1998): 107-136.

Lourenço, Miguel Rodrigues, A Articulação da Periferia. Macau e a Inquisição de Goa (c. 1582-c. 1650), Lisbon; Macau 2016.

Lourenço, Miguel Rodrigues, "Bispo da China e Inquisidor Apostólico. D. Leonardo de Sá e os inícios da representação inquisitorial em Macau", in Revista de Cultura, no. 48 (2014): 49-67.

Lourenço, Miguel Rodrigues, "Macau, porto seguro para os cristãos-novos? Problemas e métodos sobre a periferia da Inquisição de Goa", in Cadernos de Estudos Sefarditas, no. 10/11 (2011): 451-500.

Marcocci, Giuseppe, "A fé de um império: a inquisição no mundo português de Quinhentos", in Revista de História, no. 164 (2011): 65-100.

Marcocci, Giuseppe, A Consciência de um império. Portugal e o seu mundo (sécs. XV$X V I I)$, Coimbra 2012.

Marcocci, Giuseppe, "Rites and Inquisition: Ethnographies of Error in Portuguese India (156o-1625)", in Županov, Ines G, and Pierre Antonie Fabre (ed.), The Rites Controversies in the Early Modern World, Leiden; Boston 2018, 145-164.

Marcocci, Giuseppe and José Pedro Paiva, História da Inquisição Portuguesa. 1536-1821, Lisboa 2013. 
McClure, Judith, "Handbooks against heresy in the West, from the late fourth to the late sixth centuries", The Journal of Theological Studies 30, no. 1 (1979): 186-197.

Mendonça, Délio de, Conversions and Citizenry. Goa under Portugal 1510-1610, New Delhi 2002.

Metcalf, Alida C., "Millenarian Slaves? The Santidade de Jaguaripe and Slave Resistance in the Americas", in The American Historical Review 104:5 (1999): 1531-1559.

Nogueira, Eduardo Borges de Carvalho, Pagodes do Diabo. Sociedade e religião hindu na Goa portuguesa (c. 1510-c. 1560) (MA Thesis), Niterói 2012.

Wicki, José, O Livro do "Pai dos Cristãos", Lisbon 1969.

Paiva, José Pedro, Bruxaria e superstição num país sem "caça às bruxas". 1600-1774, 2nd ed., Lisbon 2002.

Paiva, José Pedro, “The Inquisition Tribunal in Goa: Why and for What Purpose?", in Journal of Early Modern History 21:6 (2017): 565-593.

Resende, Maria Leônia Chaves de (2019), “Da ignorância e rusticidade’: os indígenas e a Inquisição na América portuguesa (séculos XVI-XIX)", in Domingues, Ângela et al. (eds.), Os Indígenas e as Justiças no Mundo Ibero-Americano (Sécs. XVI-XIX), Lisbon 2019, 87-126.

Robinson, Rowena, "Taboo or Veiled Consent? Goan Inquisitorial Edict of 1736", in Economic and Political Weekly 35:27 (2000): 2423-2431.

Rubiés, Joan-Pau, "Reassessing the 'Discovery of Hinduism': Jesuit Discourse on Gentile Idolatry and the European Republic of Letters", in Amaladass, Anand and Ines G. Županov (dir.), Intercultural Encounter and the Jesuit Mission in South Asia (16th-18th Centuries), Bangalore 2014, 113-155.

Rubiés, Joan-Pau, "The Concept of a Gentile Civilization in Missionary Discourse and its European Rception. Mexico, Peru and China in the Repúblicas del Mundo by Jerónimo Román (1575-1595)", in Castelnau-l'Estoile, Charlotte de, Marie-Lucie Copete, Aliocha Maldavsky and Ines G. Županov (dir.), Missions d'Évangelisation et Circulation des Savoirs, Madrid 2011, 311-350.

Sachot, Maurice, “Religio/superstitio'. Historique d'une subversion et d'un retournement", Revue de l'histoire des religions 208:4 (1991): 355-394.

Salomon, H. P., "Les procès de l'Inquisition Portugaise comme documents littéraires, ou du bon usage du fonds inquisitorial de la Torre do Tombo", Estudos Portugueses: Homenagem a António José Saraiva, Lisbon 1990, 151-164.

Sánchez, Tomás, SJ, Opus Morale in Prcecepta Decalogi, Venice 1623.

Silva, Luiza Tonon da, Inquisição e Mestiçagem Cultural no Estado da Índia (1560-1623) (MA Thesis), Niterói 2018.

Solange, Alberro, Inquisicióny Sociedad en México, 1571-1700, Mexico 1988 (repr. Mexico 2004).

Souza, Teotónio R. de, Goa Medieval. A cidade e o interior no século XVII, Lisboa 1994. Tavares, Célia Cristina da Silva, "A Inquisição e a Companhia de Jesus diante do 'Gentilismo”, in ANPUH - XXV Simpósio Nacional de História. Anais, Fortaleza 2009, 1-9. 
Tavares, Célia Cristina da Silva, "Inquisição ao avesso: a trajetória de um inquisidor a partir dos registros da Visitação ao Tribunal de Goa”, in Topoi 10:19 (2009): 17-30.

Tavim, José Alberto Rodrigues da Silva, “'O culto ao diabo’ na Inquisição de Goa, segundo o Reportório de João Delgado Figueira (1623)”, in Anais de História de AlémMar, no. 17 (2016): 271-302.

Tavim, José Alberto Rodrigues da Silva (1997), “Um inquisidor inquirido: João Delgado Figueira e o seu Reportorio, no contexto da "documentação sobre a Inquisição de Goa", in Leituras: Revista da Biblioteca Nacional, no. 1 (1997): 183-193.

Traslosheros, Jorge, "Los indios, la Inquisición y los tribunales eclesiásticos en Nueva España. Definición jurisdiccional y justo proceso, 1571-c.1750”, in Traslosheros, Jorge and Ana de Zaballa Beascoechea (eds.), Los indios ante los foros de justicia religiosa en la Hispanoamérica virreinal, Mexico 2010, 47-74.

Vainfas, Ronaldo, A heresia dos índios. Catolicismo e rebeldia no Brasil colonial, São Paulo 1995 (repr. São Paulo 2010).

Ventura, Ricardo Nuno de Jesus, Conversão e conversabilidade. Discursos da missão e do gentio na documentação do Padroado Português do Oriente (séculos XVI e XVII) (PhD Thesis), 2 vols., Lisbon 2011.

Wadsworth, James, "Jurema and Batuque: Indians, Africans, and the Inquisition in Colonial Northeastern Brazil", in History of Religions 46:2 (November 2006):140-162.

Wicki, Ioseph, S.I. (ed.), Documenta Indica, vol. 11, Rome 1970.

Wilkinson, R. J., A Malay-English Dictionary, part 1, Singapore 1901.

Xavier, Ângela Barreto, "De converso a novamente convertido. Identidade política e alteridade no Reino e no Império", in Cultura. Revista de História e Teoria das Ideias, no. 22 (2006): 245-274.

Xavier, Ângela Barreto, A invenção de Goa. Poder imperial e conversões culturais nos séculos XVI e XVII, Lisboa 2008.

Xavier, Ângela Barreto, "Conversos and Novamente Convertidos: Law, Religion and Identity in the Portuguese Kingdom and Empire", in Journal of Early Modern History 15:3 (2011): $255^{-287}$.

Zaballa Beascoechea, Ana de, "Visitadores, extirpadores y 'tratados de idolatrías", in Saranyana, Josep Ignasi (ed.), Teología en América Latina, I-Desde los orígenes a la Guerra de Sucesión (1493-1715), Madrid 1999, 258-280.

Zaballa Beascoechea, Ana de, "Del viejo al nuevo mundo: novedades jurisdiccionales en los tribunales eclesiásticos ordinarios en Nueva España”, in Traslosheros, Jorge and Ana de Zaballa Beascoechea (eds.), Los indios ante los foros de justicia religiosa en la Hispanoamérica virreinal, México 2010, 17-46.

Županov, Ines and R. Po-Chia Hsia, "Reception of Hinduism and Buddhism", in R. Po-Chia Hsia (ed.), The Cambridge History of Christianity, vol. 6 [Reform and Expansion], Cambridge 2007, 577-597. 